\title{
Does education raise productivity and wages equally? The moderating role of age and gender
}

Stephan Kampelmann ${ }^{1}$, François Rycx ${ }^{1,3,4,5^{*}}$, Yves Saks ${ }^{2}$ and Illan Tojerow ${ }^{1,3}$

\footnotetext{
* Correspondence: frycx@ulb.ac.be ${ }^{1}$ Université libre de Bruxelles, SBS-EM, CEB and DULBEA, Avenue F. Roosevelt, 50, B-1050 Brussels, Belgium

${ }^{3}$ IZA, Bonn, Germany

Full list of author information is

available at the end of the article
}

\begin{abstract}
We estimate the impact of education on productivity, wage costs and productivitywage gaps (i.e. profits) using Belgian linked panel data. Findings highlight that educational credentials have a stronger impact on productivity than on wage costs. Firms' profitability is found to rise when lower educated workers are substituted by higher educated ones. This effect is found to be more pronounced among younger workers and women. Findings thus suggest that the productivity to wage cost ratio of low-educated workers is detrimental to their employability, especially when young or female. They also support the existence of a glass ceiling on women's career development.

JEL Classification: C33, 121, J24, J31

Keywords: Education, Labour costs, Productivity, Gender, Age Linked panel data
\end{abstract}

\section{Introduction}

Human capital theory (Becker 1964) posits that (i) education develops skills that make workers more productive and (ii) wage differentials reflect differences in productivity. Accordingly, more highly educated workers would earn higher wages ceteris paribus simply because they are more productive than their less-educated counterparts. This explanation of pay inequality has been challenged by empirical and theoretical work on labour markets. Indeed, a range of labour market theories hypothesise sources of inequality other than labour productivity, such as collective action, labour market institutions or the use of power and authority to obtain economic advantages (Berg 1981; Kalleberg and Sørensen 1979; Weeden 2002). Although each of these theories on inequality focuses on distinct social processes, they appear to have in common that they associate labour market inequality at least implicitly to an element of 'unearned' or 'unjust' allocation of resources to dominant groups. On the other hand, economists have also developed explanations of differences between productivity and wages without abandoning the assumptions of individual rationality and profit-maximising firms. In this literature, productivity-wage gaps are thought to be rational strategies of firms to address a range of market distortions (Lazear and Shaw 2007).

(c) The Author(s). 2018 Open Access This article is distributed under the terms of the Creative Commons Attribution 4.0 International License (http://creativecommons.org/licenses/by/4.0/), which permits unrestricted use, distribution, and reproduction in any medium, provided you give appropriate credit to the original author(s) and the source, provide a link to the Creative Commons license, and indicate if changes were made. 
The abundance of theories on education-driven productivity-wage gaps is not matched by a corresponding body of empirical literature. Indeed, very few studies have actually examined how the educational composition of the labour force affects firm productivity (Galindo-Rueda and Haskel 2005; Haegeland and Klette 1999; Haltiwanger et al. 1999; Moretti 2004). ${ }^{1}$ Moreover, the evidence on whether education raises productivity and wages equally is very thin, ${ }^{2}$ inconclusive and subject to various possible econometric biases (Hellerstein and Neumark 2004; Ilmakunnas and Maliranta 2005; Van Biesebroeck 2011). The endogeneity of education and the presence of firmlevel time-invariant unobserved heterogeneity are for instance seldom controlled for. Most estimates regarding the education-productivity nexus and the existence of possible education-driven productivity-wage gaps are thus potentially inconsistent. What is more, to our knowledge, no study has tried to assess whether the education-productivity-wage nexus varies with the composition of the firm's workforce in terms of age and gender. Yet, numerous arguments (notably related to information asymmetries, social norms or labour market regulations) suggest that this is probably the case. As an example, it could be noted that labour market regulations (such as minimum wages or unemployment benefits) essentially affect the lower end of the earnings distribution. As a result, these regulations are more likely to lead to a 'wage-compression effect' (i.e. a distribution of wage costs by educational groups that is more compressed than the education-productivity profile) among workers earning lower wages, e.g. younger workers (Cardoso 2010). As regards workers' gender, given that upper management jobs are mainly occupied by men, tournament theory (Lazear and Rosen 1981) for instance suggests that high-educated men have a greater likelihood to be paid above their marginal productivity. These examples, among others, suggest that workers' age and gender may have a substantial effect on the (mis)alignment of wages and productivity across educational groups. ${ }^{3}$

The aim of this paper is threefold. First, we put the relationship between the educational composition of the workforce and firm productivity to an updated test, using Belgian linked employer-employee panel data for the years 1999-2010. These data offer several advantages. The panel covers a large part of the private sector, provides accurate information on average productivity (i.e. the average value added per hour worked) and allows us to control for a wide range of worker and firm characteristics. It also enables us to address important methodological issues, such as firm-level time-invariant heterogeneity, measurement errors, reverse causality, feedback effects and state dependence of firm productivity. Indeed, early studies using the Hellerstein and Neumark approach 'have been criticized mainly due to the potential endogeneity' in the explanatory variables that have been studied (Bartolucci 2013), which can be a result of these issues. To do so, we rely on the generalised method of moments (GMM) estimator. ${ }^{4}$ A second objective is to examine whether education increases productivity and wage costs equally (i.e. to extend the analysis to productivity-wage gaps). Finally, our study provides first evidence on whether the alignment between productivity and wage costs across educational levels depends on the characteristics of workers, i.e. their age and gender.

Research questions addressed in this paper are very important for economic policy. The labour market situation of low-educated workers is particularly critical in most industrialised countries. This is also the case in Belgium (Eurostat 2016a). The unemployment rate in Belgium among the low-educated (i.e. people with less than upper secondary education) is three times larger than that among tertiary educated workers 
(16.4 vs. $4.7 \%$ in 2014). As regards the employment rate, it is found to be more than 40 percentage points lower among the former group of workers (37.3 versus $81.9 \%$ in 2014). ${ }^{5}$ Various theories, including skilled-biased technological change and competition from low-wage countries, have been put forward to explain this phenomenon (Cahuc and Zylberberg 2014). A key argument here is that low-educated workers are too costly relative to their added value. As a result, firms are willing to substitute low-educated workers by capital, to outsource part of their activities to cheap-labour countries and (especially in the case of excess labour supply) to hire more educated workers as their productivity to wage cost ratio is more favourable. ${ }^{6}$

Despite the fact that alternative theories (based on tournaments, internal decisionmaking processes of organisations, monopsony or monitoring issues) suggest that loweducated workers might actually not be too costly relative to their marginal products (Lazear and Rosen 1981; Bebchuk and Fried 2003; Osterman et al. 2009), most policies aiming to increase the employability of low-educated people in the OECD area either try to foster the latters' productivity (e.g. through specific training programmes) and/or to decrease their wage cost (e.g. through reduced payroll taxes). Belgium is no exception in this respect. Indeed, it is among the highest spenders for active labour market policies in Europe (Eurostat 2016b) and reductions in employers' and personnel social security contributions (notably targeted on the low-skilled) represent around 1.8\% of GDP (Belgian federal government 2015). While these policies are quite standard to improve the labour market prospects of low-educated people, their effectiveness is still highly controversial (Heckman et al. 1999; Cahuc and Carcillo 2012; Kluve 2010; Card et al. 2010). This is notably due to the fact that it remains unclear whether education-induced productivity gains are well aligned with corresponding wage cost differentials. In particular, more evidence is needed on whether the productivity to wage cost ratio of low-educated people is really critical for their employability. The objective of this paper is to improve our understanding of these issues with a specific focus on workers' age and gender.

The remainder of this paper is organised as follows. The following two sections, respectively, describe our methodology, estimation techniques and data set. We then analyse the impact of the composition of the workforce in term of education on productivity, wages, and productivity-wage gaps and end with a discussion of the results and a conclusion.

\section{Set-up of the analysis}

\subsection{Methodology}

The test developed in this article is based on the estimation of a value added function and a wage cost equation at the firm level. The value added function yields parameter estimates for the average impact of workers with different educational levels, while the wage equation estimates the respective impact of each educational group on the average wage bill paid by the firm. Given that both equations are estimated with the same set of firms, educational categories and covariates, the parameters for output elasticities and wages can be compared so that conclusions on educational productivity-wage gaps can be drawn. This technique was pioneered by Hellerstein et al. (1999a, 1999b) and refined by van Ours and Stoeldraijer (2011) among others. It is now standard in the literature on the productivity and wage effects of labour heterogeneity (see e.g. Cardoso et al. 2011; Devicienti et al. (2017); Garnero et al. 2014; Giuliano et al. 2017; Göbel and 
Zwick 2012; Ilmakunnas and Maliranta 2005; Mahlberg et al. 2013; Nielen and Schiersch 2014).

The estimated firm-level productivity and wage cost equations are the following:

$$
\begin{aligned}
& \ln {\text { (Value Added } / \text { Hours })_{i, t}}=\alpha+\sum_{j-\{0\}}^{J} \beta_{j} \text { Education }_{j, i, t}+\lambda X_{i, t}+\varepsilon_{i, t} \\
& \ln {\text { (Wage Cost/Hours })_{i, t}}=\alpha^{*}+\sum_{j-\{0\}}^{J} \beta_{j}^{*} \text { Education }_{j, i, t}+\lambda^{*} X_{i, t}+\varepsilon_{i, t}^{*}
\end{aligned}
$$

The dependent variable in Eq. (1) is firm i's hourly value added, obtained by dividing the total value added (at factor costs) of firm $i$ in period $t$ by the total number of hours worked (taking into account paid overtime hours) that have been declared for the same period. The dependent variable in Eq. (2) is firm i's average wage bill (including payroll taxes and variable pay components, such as wage premia for overtime, weekend or night work, performance bonuses and other premia). It is obtained by dividing the firm's total wage cost by the total number of hours worked. Hence, the dependent variables in the estimated equations are firm averages of value added and wage costs (net of social security payroll tax cuts) on an hourly basis.

The main independent variables are the shares of hours worked by each educational category in total hours worked, Education ${ }_{j, i, t}$. This is a better employment indicator than the number of employees in each category since it takes into account educational differences in working time. We split the employees of a firm into three educational groups (i.e. at most lower secondary education, at most higher secondary education, and tertiary education, respectively) and consider the share of workers with at most lower secondary education as our reference category. As a robustness test, we also consider more detailed educational groups including up to seven categories.

In addition to the shares of workers by educational level in total hours worked, we also include the vector $X_{i, t .}$. It contains a set of variables controlling for observable worker, job and firm characteristics. More precisely, it includes the share of the workforce within a firm that (i) has at least 10 years of tenure, (ii) is younger than 30 and older than 49 years, respectively, (iii) is female, (iv) works part-time, (v) occupies blue-collar jobs, (vi) has a fixed-term employment contract, and (vi) is apprentice or under contract with a temporary employment agency. $X_{i, t}$ also comprises the natural logarithm of firm size (i.e. the number of full-time equivalent workers), the natural logarithm of capital stock per worker, $^{7}$ the level of collective wage bargaining ${ }^{8}$ ( 1 dummy), sectoral affiliation (8 dummies), the region where the firm is located ( 2 dummies), and 11 year dummies. ${ }^{9}$

Estimating Eqs. (1) and (2) allows gauging the effect of education on firm productivity and wage costs, but it does not allow testing directly whether the difference between the added value and wage cost coefficients for a given educational group is statistically significant. A simple method to obtain a test for the significance of productivity-wage gaps has been proposed by van Ours and Stoeldraijer (2011). This method boils down to estimating Eq. (3):

$$
\begin{aligned}
& {\left[\ln (\text { Value Added } / \text { Hours })_{i, t}-\ln (\text { Wage Cost/Hours })_{i, t}\right]} \\
& =\alpha^{* *}+\sum_{j-\{0\}}^{J} \beta_{j}^{* *} \text { Education }_{j, i, t}+\lambda^{* *} X_{i, t}+\varepsilon_{i, t}^{* *}
\end{aligned}
$$


in which the gap between firm i's log hourly value added and log hourly wage costs (i.e. the $\log$ of the ratio between value added and wage costs) is regressed on the same set of explanatory variables as in Eqs. (1) and (2). This produces coefficients for the educational variables and directly measures the size and significance of their respective productivity-pay gaps.

In light of the so-called persistence of profits literature (see e.g. Bou and Satorra 2007), there are strong theoretical arguments for adding a dynamic element to Eqs. (1) to (3). The assumption of persistent productivity and wages both at the industry and firm level also finds some support in the literature. According to Syverson (2011: 326), different studies 'documented, virtually without exception, enormous and persistent measured productivity differences across producers, even within narrowly defined industries'. Large parts of these productivity differences are still hard to explain. The persistence of wage costs is also highlighted in the literature (see e.g. Fuss and Wintr 2009). Wage stickiness is notably the outcome of labour market institutions, adjustment costs and efficiency wages' motives. It is therefore standard in the literature to use dynamic panel data methods such as those proposed by Arellano and Bond (1991) to overcome lag dependency. Accordingly, many papers rely on the dynamic generalised method of moments (GMM) to estimate the impact of workforce and job characteristics on productivity and/or labour costs (see e.g. Cardoso et al. 2011; Giuliano et al. 2017; Göbel and Zwick 2012; Mahlberg et al. 2013; Nielen and Schiersch 2014; van Ours and Stoeldraijer 2011).

\subsection{Estimation techniques}

Equations (1) to (3) have been estimated with four different methods: pooled ordinary least squares (OLS), a fixed-effects (FE) model and the GMM estimator developed by Arellano and Bover (1995) and Blundell and Bond (1998). For the added value function, we also follow Levinsohn and Petrin (2003) and provide results based on their (LP) estimator, which is particularly well-suited for panels with small $t$ and big $N$, controls for endogeneity by using the firms' intermediate inputs (i.e. inputs such as energy, raw material, semi-finished goods and services that are typically subtracted from gross output to obtain added value) to proxy for unobserved productivity shocks. The intuition is that firms respond to time-varying productivity shocks observed by managers (and not by econometricians) through the adjustment of their intermediate inputs. Put differently, profit-maximising firms react to positive (negative) productivity shocks by increasing (decreasing) their output, which requires more (less) intermediate inputs.

The OLS estimator is based on the cross-sectional variability between firms and the longitudinal variability within firms over time. However, this OLS estimator suffers from not accounting for firm-specific time-invariant characteristics that are not measured in micro-level surveys (e.g. an advantageous location, firm-specific assets such as patent ownership, or other firm idiosyncrasies).

The conventional way to remove unobserved firm characteristics that remained unchanged during the observation period is by estimating a fixed effects (FE) model. This boils down to estimate a within differentiated model, i.e. a model where the mean of each variable has been subtracted from the initial values. This approach cannot be applied for the firms in our sample: the variable of interest, i.e. the shares of workers by 
level of education, does not show sufficient variation over time to be a useful explanatory variable for firm-level wages or productivity after mean differencing (see e.g. Wooldridge 2010). Moreover, neither pooled OLS nor the FE estimator address the potential endogeneity of our explanatory variables. ${ }^{10}$ Yet, as highlighted by Gautier et al. (2002: 523), 'employers might exploit cyclical downturns to improve the average skill level of their work force'. To put it differently, there might be some cyclical 'crowding out', namely a process by which during recessions-because of excess labour supply-highly educated workers take the jobs that could be occupied by less-educated ones. This assumption, supported empirically for certain countries including Belgium (Cockx and Dejemeppe 2002; Dolado et al. 2000), suggests that the share of more educated workers within firms may increase as a result of lower labour productivity (and vice versa). We have performed a direct endogeneity test on the educational variables in our sample and indeed reject the null hypothesis that our main variables of interest can actually be treated as exogenous. ${ }^{11}$ To control for this endogeneity issue, in addition to temporal persistence in the dependent variable (firm productivity, wage costs or profits) and firm fixed unobserved heterogeneity, we estimate Eqs. (1) to (3) with the dynamic system GMM (GMM-SYS).

The GMM-SYS approach implies to simultaneously estimate a system of two equations (respectively in level and in first differences) and rely on internal instruments to control for endogeneity. More precisely, educational variables ${ }^{12}$ are instrumented by their lagged levels in the differenced equation and by their lagged differences in the level equation. ${ }^{13}$ The implicit assumption is that changes (the level) in (of) the dependent variable-productivity, salary costs or profits-in one period are uncorrelated with lagged levels (differences) of the latter. Moreover, changes (levels) in (of) educational variables are assumed to be reasonably correlated to their past levels (changes). ${ }^{14}$

One advantage of the system GMM is that time-invariant explanatory variables can be included among the regressors, while they typically disappear in difference GMM. Asymptotically, the inclusion of these variables does not affect the estimates of the other regressors because instruments in the level equation (i.e. lagged differences of educational variables) are expected to be orthogonal to all time-invariant variables (Roodman 2009). To examine the validity of our estimates, we apply Hansen's (1982) and Arellano and Bond's (1991) tests. The first is a test for overidentification which allows to test the validity of the instruments. The second is a test for autocorrelation, where the null hypothesis assumes no second order autocorrelation in the first differenced errors. The non-rejection of the two tests is required in order to assume that our estimates are reliable.

The adoption of a dynamic GMM specification aims to account for the persistency in firm-level profits, wage costs and productivity. It is also likely to improve the identification of the parameters of interest (even though the coefficient on the lagged dependent variable is not a central issue in the analysis). Indeed, as illustrated by Bond (2002), the use of a dynamic model is necessary to obtain consistent results when estimating a production function with serially correlated productivity shocks and explanatory variables that are correlated to these shocks. While serial correlation of productivity shocks may arise if for instance the effects of demand shocks are only partially captured by the industry-specific control variables (Hempell, 2005), the responsiveness of input factors to productivity shocks may be explained by the abovementioned endogeneity issue. Interestingly, the inclusion of the lagged dependent variable in the OLS, fixed-effects 
and system GMM specifications also provides an ad hoc test for the appropriateness of the latter. As outlined by Roodman (2009), this test consists in checking whether or not the regression coefficient on the lagged dependent variable obtained with system GMM falls between the OLS and fixed effects estimates. ${ }^{15}$

\section{Data and descriptive statistics}

We use a combination of two large datasets covering the years 1999-2010. The first is the 'Structure of Earnings Survey' (SES), carried out by Statistics Belgium. It covers all firms that are operating in Belgium, employ more than 10 workers and have economic activities within sections $\mathrm{C}$ to $\mathrm{K}$ of the NACE Rev. 1 nomenclature. ${ }^{16}$ This survey gathers information on firms' characteristics (e.g. sector, region where the firm is located, number of workers, level of collective wage bargaining) as well as information on workers' characteristics (e.g. age, education, tenure, paid hours, gender, occupation, employment contract). However, the SES does not provide any financial information. It has thus been merged with a firm-level survey, namely the 'Structure of Business Survey' (SBS), also carried out by Statistics Belgium. This survey provides financial information (e.g. firm-level wage cost, value added and gross operating surplus per hour worked). The coverage of the SBS differs from that of the SES in that it does not cover the whole financial sector (NACE J) but only Other Financial Intermediation (NACE 652) and Activities Auxiliary to Financial Intermediation (NACE 67). The merger of the SES and SBS datasets has been carried out by Statistics Belgium using firms' social security numbers.

Information in the SES refers to the month of October of each year, while data in the SBS are measured over entire calendar years, i.e. from January to December. To avoid running a regression where information on the dependent variable (collected for the entire year) precedes the recording of the explanatory variables (collected in October), all explanatory variables in Eqs. (1) to (3) have been lagged by 1 year. This way, information on educational variables is recorded in October in year $t$ and used to explain firm-level productivity, wage costs and productivity-wage gaps during the calendar year $t+1$. The imperfect synchronisation of the SBS and SES data might introduce some fuzziness into our estimates since we cannot exclude the occurrence of external events influencing firm performance in the intermediate period. This concern could only be completely eliminated if we had firm-level information on educational variables for the entire calendar year. This being said, even if this information were available, there is a compelling argument for using asynchronised information on educational variables: it is difficult to conceive how changes in shares of workers by educational level could generate immediate effects notably on firm productivity and productivity-wage gaps. Potential effects are indeed more likely to occur after a certain adjustment period. The slightly asynchronised use of SBS and SES is therefore arguably the best option in light of data availability and firm performance dynamics.

As a consequence, our sample contains firms that are observed in at least two consecutive years and thus over-represents medium-sized and large firms since the sampling percentages for each firm in our dataset increase with the size of the latter. ${ }^{17}$ Next, we exclude workers and firms for which data are missing or inaccurate. ${ }^{18}$ Finally, we drop firms with fewer than 10 observations (i.e. with information on less than 10 employees in a given year), because the use of average values at the firm level requires a suitable number of observations. ${ }^{19}$ Firm-level averages used in the regression analysis below are computed by taking into account the sampling weights that ensure the 
representativeness of the employee sample. Since we have to delete observations with missing information for some variables and firms that are not observed in at least two consecutive years, we do not work with the complete sample of the SES-SBS. It is therefore worthwhile to verify whether the composition of the sample in terms of educational credentials is affected by the reduction in the sample size. Appendix 9 shows average values and standard deviations for average firm shares of three levels of educational attainment in (a) the complete sample, (b) the sample for which all variables of interest are non-missing and (c) the final sample with non-missing information and firms that are observed in at least two consecutive years. We conclude from this exercise that both the average values and the standard deviations are relatively stable across sub-samples. Our final sample covering the period 1999-2010 consists of an unbalanced panel of 6714 firm-year-observations from 1844 firms. In summary, our sample is therefore representative of all medium-sized and large firms in the Belgian private sector, with the exception of large parts of the financial sector (NACE J) and the electricity, gas and water supply industry (NACE E), because (a) both the SES and SBS are based on official surveys of administrative data collected from a large representative sample of the Belgian private sector, (b) we drop small firms for which we have less than 10 employee observations and (c) we drop firms from the public sector as well as large parts of sectors NACE J and NACE E, which are underrepresented in the data.

Descriptive statistics of selected variables are presented in Table 1. We observe that firms have a mean value added per hour worked of 66.19 EUR and that workers' mean hourly wage cost stands at 33.34 EUR. $^{20}$ Average hourly profits (i.e. gross operating surplus) are equal to 32.85 EUR. As regards the educational composition of the labour force, in our sample, the share of workers with at most lower secondary education stands at around 30\%, the fraction of workers with higher secondary educational attainment reaches approximately $42 \%$, and about $28 \%$ of employees have a degree of tertiary education. The share of higheducated (low-educated) workers is approximately 3 percentage points higher (lower) than in the raw SES-SBS sample, suggesting that high-educated (low-educated) workers are somewhat over-represented (under-represented) in the sample we use in our regression analysis.

Employees in our sample are essentially concentrated in the manufacturing industry (58\%), wholesale and retail trade, repair of motor vehicles, motorcycles and personal and household goods (12\%), construction (10\%), real estate, renting and business activities $(10 \%)$, and transport, storage and communication (6\%). Moreover, firms employ on average $26 \%$ of women, $62 \%$ of prime-age workers (i.e. workers aged between 30 and 49 years), $40 \%$ of employees with less than 10 years of tenure, $53 \%$ of blue-collar workers, $11 \%$ of part-time workers, and $3 \%$ of workers with a fixed-term employment contract. Also noteworthy is that $57 \%$ of workers are employed in Flanders, $28 \%$ in Wallonia and 15\% in Brussels. Finally, as regards collective bargaining, Table 1 shows that $32 \%$ of workers are covered by a firmlevel collective agreement (in addition to an industry-level agreement).

\section{Results}

4.1 Benchmark estimates

Given the abovementioned econometric issues associated with pooled OLS and FE estimates, we directly report findings based on the dynamic GMM-SYS estimator. ${ }^{21}$ 
Table 1 Descriptive statistics at the firm level (1999-2010)

\begin{tabular}{|c|c|c|}
\hline Variables & Mean & Std. Dev. \\
\hline Value added per hour $\left(€^{\mathrm{a}}\right)$ & 66.19 & 526.00 \\
\hline In(value added per hour) & 3.85 & 0.54 \\
\hline Wage cost per hour $\left(€^{a}\right)$ & 33.34 & 19.62 \\
\hline $\ln ($ wage cost per hour) & 3.44 & 0.33 \\
\hline $\begin{array}{l}\text { Gross profit per hour }\left(€^{\mathrm{a}}\right) \text {, i.e. value added } \\
\text { per hour - wage cost per hour }\end{array}$ & 32.85 & 524.56 \\
\hline $\begin{array}{l}\text { In(gross profit per hour), i.e. In(value added } \\
\text { per hour - wage cost per hour) }\end{array}$ & 2.41 & 1.21 \\
\hline $\begin{array}{l}\text { Value added-wage cost gap, i.e. In(value added } \\
\text { per hour) - In(wage cost per hour) }\end{array}$ & 0.41 & 0.37 \\
\hline Share of low-educated workers (E12): & 0.30 & 0.295 \\
\hline - Primary education (E1) & 0.07 & 0.16 \\
\hline - Lower secondary education (E2) & 0.23 & 0.26 \\
\hline Share of middle-educated workers (E34) & 0.43 & 0.27 \\
\hline - Upper general secondary education (E3) & 0.21 & 0.24 \\
\hline $\begin{array}{l}\text { - Upper technical or professional secondary } \\
\text { education (E4) }\end{array}$ & 0.22 & 0.25 \\
\hline Share of high-educated workers (E567): & 0.28 & 0.25 \\
\hline - Bachelor's or equivalent level (E5) & 0.16 & 0.16 \\
\hline - Master's or equivalent level (E6) & 0.11 & 0.15 \\
\hline - Post-Master' education or PhD (E7) & 0.01 & 0.03 \\
\hline Workers with 10 years of tenure or more (\%) & 0.40 & 0.23 \\
\hline Share of workers $<30$ years & 0.21 & 0.13 \\
\hline Share of workers $>49$ years & 0.17 & 0.12 \\
\hline Women (\%) & 0.26 & 0.23 \\
\hline Part-time (less than $30 \mathrm{~h}$ per week, \%) & 0.11 & 0.13 \\
\hline Blue-collar workers (\%) & 0.53 & 0.33 \\
\hline Fixed-term employment contacts (\%) & 0.03 & 0.08 \\
\hline Apprentices (\%) & 0.00 & 0.01 \\
\hline Temporary agency workers (\%) & 0.00 & 0.04 \\
\hline Mining and quarrying $(C)$ & 0.01 & 0.09 \\
\hline Manufacturing (D) & 0.58 & 0.49 \\
\hline Electricity, gas and water supply (E) & 0.00 & 0.06 \\
\hline Construction (F) & 0.10 & 0.30 \\
\hline $\begin{array}{l}\text { Wholesale and retail trade, repair of motor } \\
\text { vehicles, motorcycles and personal and } \\
\text { household goods }(G)\end{array}$ & 0.12 & 0.33 \\
\hline Hotels and restaurant $(\mathrm{H})$ & 0.01 & 0.12 \\
\hline Transport, storage and communication (I) & 0.06 & 0.23 \\
\hline Financial intermediation $(J)$ & 0.02 & 0.13 \\
\hline Real estate, renting and business activities ( $K$ ) & 0.10 & 0.30 \\
\hline Firm-level collective agreement (\%) & 0.32 & 0.46 \\
\hline Brussels & 0.15 & 0.34 \\
\hline Flanders & 0.57 & 0.48 \\
\hline Wallonia & 0.28 & 0.43 \\
\hline Capital stock $\left(€^{\mathrm{a}}\right)$ & 236,013 & $2,095,986$ \\
\hline
\end{tabular}


Table 1 Descriptive statistics at the firm level (1999-2010) (Continued)

\begin{tabular}{lll}
\hline Variables & Mean & Std. Dev. \\
\hline Number of observations & 6714 & \\
Number of firms & 1844 & \\
\hline
\end{tabular}

${ }^{\mathrm{a} A t} 2004$ constant prices. Own calculations based on SES-SBS data

For the value added equation, we also provide estimation results using the more structural Levinson-Petrin method, which corroborate the GMM-SYS estimates for this equation. Table 2 shows the impact of shares of workers by level of education on hourly productivity, wage costs and productivity-pay gaps ${ }^{22}$ at the firm level. Workers have been split in three educational groups according to whether they had (i) at most lower secondary education (low-educated workers), (ii) an upper secondary educational attainment (middle-educated workers) and (iii) at least an undergraduate degree (high-educated workers). The share of low-educated workers serves as reference category.

GMM-SYS estimates are reported in columns (1) to (3). ${ }^{23}$ To examine their reliability, we first apply the Hansen and Arellano-Bond tests. For all regressions, they do not reject respectively the null hypotheses of valid instruments ${ }^{24}$ and of no second order autocorrelation in the first differenced errors. ${ }^{25}$ Results in column (1) indicate that middle- and high-educated workers are significantly more productive than low-educated workers. They also show ${ }^{26}$ that the productivity of middle-educated workers is significantly smaller than that of high-educated workers. The regression coefficient associated with the share of middle-educated workers is equal to 0.106 . This means that if the fraction of middleeducated workers within a firm increases by 10 percentage points (and is compensated by a proportional decrease in the share of low-educated workers), mean hourly productivity rises on average by $1.06 \%$ (i.e. $0.106 \times 0.10=0.0106=1.06 \%$ ). Similarly, estimates suggest that increasing the share of high-educated workers by 10 percentage points at the expense of loweducated (middle-educated) workers increases firm hourly productivity on average by $2.58 \%$ (1.52\%). LP results, reported in column (4), confirm that workers' educational attainment has a significant positive influence on firm-level productivity. Estimates indeed suggest that hourly value added rises on average by respectively 1.28 and $0.19 \%$ following a 10 percentage point increase in the incidence of high- and middle-educated workers (at the expense of the reference educational group). They also indicate that productivity grows on average by $1.09 \%$ if the share of high-educated workers increases by 10 percentage points and is compensated by a proportional decrease in the fraction of middle-educated workers.

Turning to the relationship between education and wage costs, results show (see column (2)) that a 10 percentage points rise in the share of middle-educated (high-educated) workers, at the expense of low-educated workers, increases mean hourly wage costs on average by $0.27 \%(1.45 \%)$. Moreover, they suggest that wage costs rise on average by $1.18 \%$ if the share of high-educated workers is increased by 10 percentage points and compensated by a comparable decrease in the incidence of middle-educated workers. Findings thus support the existence of a significant upward-sloping relation between education and wage costs.

In order to determine whether marginal wage costs of different educational groups are in line with corresponding output elasticities, we re-estimated our benchmark equation using as dependent variable the value added-wage cost gap. Results, reported in 
Table 2 Estimates for the entire sample, three educational categories

\begin{tabular}{|c|c|c|c|c|}
\hline & \multicolumn{3}{|l|}{ GMM-SYS } & \multirow{2}{*}{$\begin{array}{l}\text { LP } \\
\text { Value added per } \\
\text { hour worked (In) }\end{array}$} \\
\hline & $\begin{array}{l}\text { Value added per } \\
\text { hour worked (In) }\end{array}$ & $\begin{array}{l}\text { Wage cost per hour } \\
\text { worked (In) }\end{array}$ & $\begin{array}{l}\text { Value added- } \\
\text { wage cost gap }\end{array}$ & \\
\hline & $(1)$ & (2) & (3) & (4) \\
\hline Lagged dependent variable (In) & $\begin{array}{l}0.619^{* * *} \\
(0.050)\end{array}$ & $\begin{array}{l}0.447^{* * *} \\
(0.135)\end{array}$ & $\begin{array}{l}0.613^{* * *} \\
(0.046)\end{array}$ & $\begin{array}{l}0.791^{* * *} \\
(0.043\end{array}$ \\
\hline \multicolumn{5}{|l|}{ Shares of worker ${ }^{a}$} \\
\hline Low-educated (E12) & Reference & Reference & Reference & Reference \\
\hline Middle-educated (E34) & $\begin{array}{l}0.106^{* *} \\
(0.053)\end{array}$ & $\begin{array}{l}0.027^{* *} \\
(0.013)\end{array}$ & $\begin{array}{l}0.027 \\
(0.021)\end{array}$ & $\begin{array}{l}0.019^{* *} \\
(0.009)\end{array}$ \\
\hline High-educated (E567) & $\begin{array}{l}0.258^{* * *} \\
(0.092)\end{array}$ & $\begin{array}{l}0.145^{* * *} \\
(0.047)\end{array}$ & $\begin{array}{l}0.055^{*} \\
(0.031)\end{array}$ & $\begin{array}{l}0.128^{* * *} \\
(0.026)\end{array}$ \\
\hline $\begin{array}{l}\text { Hansen over-identification test, } \\
p \text { value }\end{array}$ & 0.175 & 0.132 & 0.619 & \\
\hline $\begin{array}{l}\text { Arellano-Bond test for } \mathrm{AR}(2) \text {, } \\
p \text { value }\end{array}$ & 0.384 & 0.342 & 0.219 & \\
\hline Number of observations & 6714 & 6714 & 6714 & 6691 \\
\hline Number of firms & 1844 & 1844 & 1844 & 1844 \\
\hline \multicolumn{5}{|l|}{$\begin{array}{l}\text { Chi-squared statistic for } \\
\text { equality of regression } \\
\text { coefficients, } \mathrm{H}_{0}\end{array}$} \\
\hline$E 34=E 567$ & $2.85^{*}$ & $6.24^{* *}$ & 1.15 & $17.83^{* * *}$ \\
\hline \multirow[t]{3}{*}{ Interpretation ${ }^{b}$} & E12<E34 & $\mathrm{E} 12<\mathrm{E} 34$ & $\mathrm{E} 12<\mathrm{E} 567$ & E12<E34 \\
\hline & $\begin{array}{l}\mathrm{E} 12<\mathrm{E} 567 \\
\mathrm{E} 34<\mathrm{E} 567\end{array}$ & $\begin{array}{l}\mathrm{E} 12<\mathrm{E} 567 \\
\mathrm{E} 34<\mathrm{E} 567\end{array}$ & $\begin{array}{l}\text { but } \\
\mathrm{E} 12=\mathrm{E} 34 \\
\mathrm{E} 34=\mathrm{E} 567\end{array}$ & $\begin{array}{l}\mathrm{E} 12<\mathrm{E} 567 \\
\mathrm{E} 34<\mathrm{E} 567\end{array}$ \\
\hline & $\begin{array}{l}\Rightarrow \text { Education } \\
\text { increases } \\
\text { productivity }\end{array}$ & $\begin{array}{l}\Rightarrow \text { Education } \\
\text { increases } \\
\text { wage costs }\end{array}$ & $\begin{array}{l}\Rightarrow \text { E567 more } \\
\text { profitable } \\
\text { than E12 }\end{array}$ & $\begin{array}{l}\Rightarrow \text { Education } \\
\text { increases } \\
\text { productivity }\end{array}$ \\
\hline
\end{tabular}

Notes: Standard errors, that are robust to heteroskedasticity and autocorrelation, are reported between parentheses. Regressions also control for: \% of workers with 10 years of tenure or more; \% workers younger than 30 and older than 49 years, respectively; \% women; \% part-time workers; \% blue-collar workers; \% workers with fixed term employment contract; \% apprentices; \% temporary agency workers; In of firm size; In of capital stock per worker; level of collective wage bargaining; region where the firm is located (2 dummies); industries ( 8 dummies), and years dummies (11). AR (2) refers to second-order autocorrelation in first-differenced errors. GMM-SYS specifications include first and second lags of explanatory variables (except time dummies) as instruments ${ }^{* * *} p<0.01,{ }^{* * *} p<0.05,{ }^{*} p<0.1$

${ }^{a}$ Low-educated workers (E12) have at most a degree of lower secondary school. Middle-educated workers (E34) have at most a degree from upper (general, technical or professional) secondary school. High-educated workers (E567) have a tertiary educational attainment (i.e. at least a Bachelor's or equivalent degree)

$b^{\prime}{ }^{\prime}<{ }^{\prime}\left({ }^{\prime}={ }^{\prime}\right)$ indicates if regression coefficients are (not) statistically different at the $10 \%$ level

c Value added-wage cost gap $=\ln$ (value added per hour) $-\ln$ (wage cost per hour)

column (3) of Table 2, suggest that firm rents increase when low-educated workers are substituted by high-educated ones. Indeed, estimates show that the productivity-pay gap rises on average by $0.55 \%$ following a 10 percentage point increase in the share of high-educated workers (at the expense of low-educated ones). The additional value generated by high-educated workers relative to their low-educated co-workers is thus found to exceed their wage cost differential. In sum, findings in column (3) suggest that high-educated workers are under-paid relative to their low-educated counterparts (and vice versa). ${ }^{27,28,29}$

To fine-tune our understanding of the education-productivity-pay nexus, we re-estimated our benchmark specification using seven rather than three educational categories. ${ }^{30}$ While the inclusion of additional educational variables is likely to increase the standard errors of our estimates (as the share of observations within each educational 
group decreases), results reported in Appendix 4 actually support and refine our conclusions. Indeed, they show a significant upward-sloping profile between education and wage costs, on the one hand, and education and productivity, on the other. They also indicate (see estimates in columns (3)) that low-educated workers tend to be over-paid relative to other educational groups. Decreasing their share at the benefit of more educated groups of employees appears indeed to be beneficial for firms' productivity-wage gaps. Findings thus corroborate the hypothesis that the distribution of wage costs across educational groups is more compressed than the education-productivity profile. More precisely, they support the existence of a 'wage-compression effect' according to which the substitution of low- by high-educated workers increases employer rents (and vice versa). ${ }^{31}$

\subsection{Estimates across groups of workers}

Various theoretical arguments suggest that the education-productivity-pay nexus may depend on workers' age and gender. As an example, it could be noted that labour market regulations (such as minimum wages or unemployment benefits) essentially affect the lower end of the earnings distribution. As a result, these regulations are more likely to lead to a 'wage-compression effect' among workers earning lower wages, e.g. young and female workers (Cardoso 2010). Given the importance of this issue and the lack of empirical results, this section examines these interaction effects in more detail.

\subsubsection{Does workers' age matter?}

We first focus on the potential impact of workers' age. To do so, we re-estimated Eqs. (1) to (3), including the education and age share variables in interaction. More precisely, we computed shares of hours worked respectively by young and older workers of different educational groups within firms and estimated their effects on productivity, wage costs and productivity-wage gaps. In order to guarantee that the number of observations in each education-age group was sufficiently large (i.e. to maximise the robustness of our estimates), we fixed the threshold separating young from older workers at 40 years. ${ }^{32} \mathrm{Next}$, following our baseline specification, we split young and older workers in three educational groups. We thus differentiated workers according to whether they were (i) low-educated (i.e. had at most lower secondary education), (ii) middle-educated (i.e. had upper secondary educational attainment), or (iii) high-educated (i.e. had at least an undergraduate degree). The share of young low-educated workers has been used as reference category.

Results are reported in Table 3. GMM-SYS and LP estimates show (on the basis of chisquared statistics testing for the equality of regressions coefficients) that older workers' educational level has a significantly positive impact wage costs and productivity. ${ }^{33}$ They also suggest that education-driven productivity gains among older workers are in line with wage cost differentials. Indeed, older workers' educational level is not found to affect the productivity-pay gap. Estimates among young workers are somewhat different. On the one hand, they confirm the existence of a positive impact of educational credentials on wage costs and value added. More precisely, they show that young high-educated workers are more productive and costly than young low- and middle-educated workers. On the other hand, they highlight that educational credentials among young workers have a stronger impact on productivity than on wage costs. Results indicate that firms' rents (measured through the value-added/wage cost gap) rise when young low-educated workers are replaced by young high-educated workers (and vice versa). 
Table 3 Estimates according to workers' age (threshold $=40$ years ${ }^{\mathrm{a}}$ ), three educational categories

\begin{tabular}{|c|c|c|c|c|}
\hline & \multicolumn{3}{|l|}{ GMM-SYS } & \multirow{2}{*}{$\begin{array}{l}\text { LP } \\
\text { Value added per } \\
\text { hour worked (In) }\end{array}$} \\
\hline & $\begin{array}{l}\text { Value added per } \\
\text { hour worked (In) }\end{array}$ & $\begin{array}{l}\text { Wage cost per } \\
\text { hour worked (In) }\end{array}$ & $\begin{array}{l}\text { Value added- } \\
\text { wage cost gap }\end{array}$ & \\
\hline & (1) & (2) & (3) & (4) \\
\hline $\begin{array}{l}\text { Lagged } \\
\text { dependent } \\
\text { variable (In) }\end{array}$ & $\begin{array}{l}0.659^{* * *} \\
(0.058)\end{array}$ & $\begin{array}{l}0.465^{* * *} \\
(0.138)\end{array}$ & $\begin{array}{l}0.614^{* * *} \\
(0.047)\end{array}$ & $\begin{array}{l}0.792^{* * *} \\
(0.043)\end{array}$ \\
\hline \multicolumn{5}{|c|}{ Shares of workers ${ }^{\mathrm{a}}$} \\
\hline $\begin{array}{l}\text { Young low- } \\
\text { educated } \\
\text { (YE12) }\end{array}$ & Reference & Reference & Reference & Reference \\
\hline $\begin{array}{l}\text { Older low- } \\
\text { educated } \\
\text { (OE12) }\end{array}$ & $\begin{array}{l}-0.028 \\
(0.055)\end{array}$ & $\begin{array}{l}-0.010 \\
(0.039)\end{array}$ & $\begin{array}{l}-0.034 \\
(0.046)\end{array}$ & $\begin{array}{l}-0.026 \\
(0.032)\end{array}$ \\
\hline $\begin{array}{l}\text { Young } \\
\text { middle- } \\
\text { educated } \\
\text { (YE34) }\end{array}$ & $\begin{array}{l}0.046 \\
(0.044)\end{array}$ & $\begin{array}{l}0.004 \\
(0.022)\end{array}$ & $\begin{array}{l}0.040 \\
(0.043)\end{array}$ & $\begin{array}{l}-0.017 \\
(0.022)\end{array}$ \\
\hline $\begin{array}{l}\text { Older } \\
\text { middle- } \\
\text { educated } \\
\text { (OE34) }\end{array}$ & $\begin{array}{l}0.039 \\
(0.047)\end{array}$ & $\begin{array}{l}0.059^{*} \\
(0.034)\end{array}$ & $\begin{array}{l}-0.033 \\
(0.043)\end{array}$ & $\begin{array}{l}0.035 \\
(0.022)\end{array}$ \\
\hline $\begin{array}{l}\text { Young } \\
\text { high- } \\
\text { educated } \\
\text { (YE567) }\end{array}$ & $\begin{array}{l}0.158^{* * *} \\
(0.058)\end{array}$ & $\begin{array}{l}0.096^{* *} \\
(0.048)\end{array}$ & $\begin{array}{l}0.093^{* *} \\
(0.045)\end{array}$ & $\begin{array}{l}0.120^{* * *} \\
(0.033)\end{array}$ \\
\hline $\begin{array}{l}\text { Older high- } \\
\text { educated } \\
\text { (OE567) }\end{array}$ & $\begin{array}{l}0.080 \\
(0.069)\end{array}$ & $\begin{array}{l}0.235^{* * *} \\
(0.080)\end{array}$ & $\begin{array}{l}-0.029 \\
(0.056)\end{array}$ & $\begin{array}{l}0.106^{* * *} \\
(0.036)\end{array}$ \\
\hline $\begin{array}{l}\text { Hansen over- } \\
\text { identification } \\
\text { test, } p \text { value }\end{array}$ & 0.451 & 0.238 & 0.799 & \\
\hline $\begin{array}{l}\text { Arellano- } \\
\text { Bond test for } \\
\text { AR(2), } p \text { value }\end{array}$ & 0.132 & 0.306 & 0.224 & \\
\hline $\begin{array}{l}\text { Number of } \\
\text { observations }\end{array}$ & 6714 & 6714 & 6714 & 6691 \\
\hline $\begin{array}{l}\text { Number of } \\
\text { firms }\end{array}$ & 1844 & 1844 & 1844 & 1844 \\
\hline \multicolumn{5}{|c|}{$\begin{array}{l}\text { Chi-squared statistic for equality } \\
\text { of regression coefficients, } H_{0}\end{array}$} \\
\hline $\begin{array}{l}\text { OE12 = } \\
\text { YE34 }\end{array}$ & 1.94 & 0.17 & 2.58 & 0.13 \\
\hline $\begin{array}{l}\mathrm{OE} 12= \\
\mathrm{OE} 34\end{array}$ & 2.14 & $5.14^{* *}$ & 0.00 & $5.27^{* *}$ \\
\hline $\begin{array}{l}\text { OE12 = } \\
\text { YE567 }\end{array}$ & $8.62^{* * *}$ & $4.21^{* *}$ & $6.38^{* *}$ & $20.39^{* * *}$ \\
\hline $\begin{array}{l}\text { OE12= } \\
\text { OE567 }\end{array}$ & 2.36 & $7.73^{* * *}$ & 0.01 & $11.25^{* * * *}$ \\
\hline $\begin{array}{l}\text { YE34 = } \\
\text { OE34 }\end{array}$ & 0.01 & 2.22 & 1.43 & $2.96^{*}$ \\
\hline $\begin{array}{l}\text { YE34 = } \\
\text { YE567 }\end{array}$ & $4.68^{* *}$ & $3.48^{*}$ & 1.94 & $17.51^{* * *}$ \\
\hline $\begin{array}{l}\text { YE34 = } \\
\text { OE567 }\end{array}$ & 0.22 & $7.58^{* * *}$ & 1.26 & $8.87^{* * *}$ \\
\hline $\begin{array}{l}\text { OE34= } \\
\text { YE567 }\end{array}$ & $3.01^{*}$ & 0.64 & $4.34^{* *}$ & $9.34^{* * *}$ \\
\hline
\end{tabular}


Table 3 Estimates according to workers' age (threshold $=40$ years ${ }^{a}$ ), three educational categories (Continued)

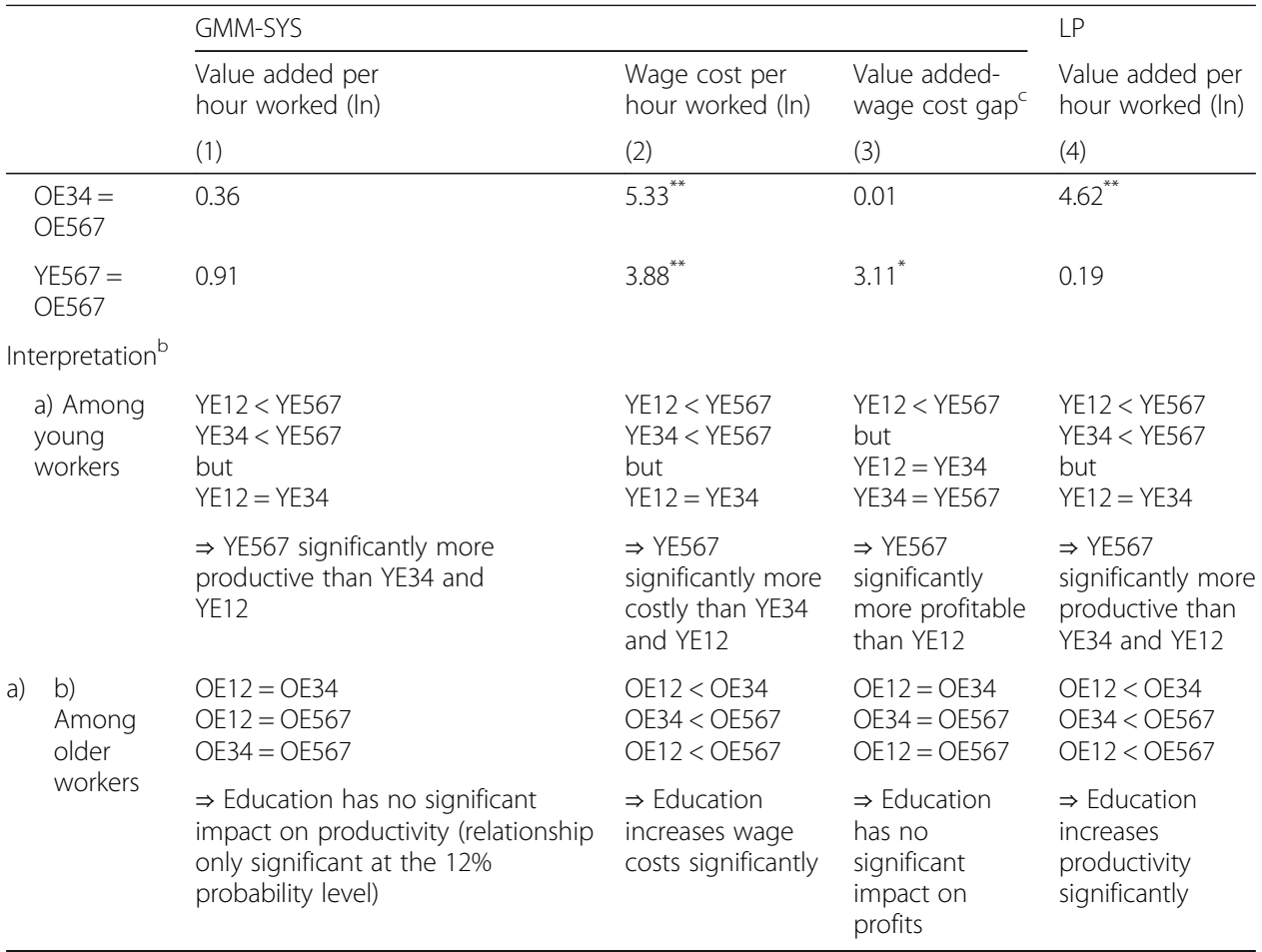

Notes: Standard errors, that are robust to heteroskedasticity and autocorrelation, are reported between parentheses. Regressions also control for: \% of workers with 10 years of tenure or more; \% workers younger than 30 and older than 49 years, respectively; \% women; \% part-time workers; $\%$ blue-collar workers; $\%$ workers with fixed term employment contract; \% apprentices; \% temporary agency workers; In of firm size; In of capital stock per worker; level of collective wage bargaining; region where the firm is located (2 dummies); industries ( 8 dummies), and years dummies (11). AR (2) refers to second-order autocorrelation in first-differenced errors. Models (1) and (3) include first and second lags of explanatory variables (except time dummies) as instruments. Model (2) uses first and third lags of explanatory variables (except time dummies) as instruments

${ }^{* * *} p<0.01,{ }^{* * *} p<0.05,{ }^{*} p<0.1$

${ }^{a}$ Young (older) workers are defined as being less than (at least) 40 years old. Low-educated workers (E12) have at most a degree of lower secondary school. Middle-educated workers (E34) have at most a degree from upper (general, technical or professional) secondary school. High-educated workers (E567) have a tertiary educational attainment (i.e. at least a Bachelor's or equivalent degree)

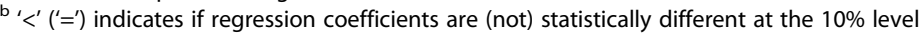

c Value added-wage cost gap $=\ln$ (value added per hour) $-\ln$ (wage cost per hour)

As a sensitivity test, we re-estimated our model using four rather than three educational categories and kept the threshold to separate young from older workers at 40 years. Regression results, reported in Appendix 7, support previous findings according to which education increases productivity and wage costs both among young and older workers. They also suggest that the under-payment (overpayment) of high-educated (low-educated) workers disappears among older cohorts of employees (see column (3)). In sum, it appears that the existence of a 'wagecompression effect' is essentially verified among young workers. For older workers, estimates indicate that the distribution of wage costs across educational groups is well aligned with workers' educational productivity profile.

\subsubsection{Does workers' gender matter?}

In order to examine whether the education-productivity-pay nexus depends on workers' gender, we re-estimated Eqs. (5) to (7), including shares of hours worked respectively by female and male workers with different educational attainments within 
firms. In line with our baseline specification, we first focused on low-, middle- and high-educated workers. GMM-SYS and LP estimates, reported in Table 4, show that women's and men's education exerts a significantly positive impact on wage costs and productivity. Yet, the relationship between education and wage costs is found to be quite weak for women and definitely weaker than for men. For male workers, we also find that education-driven productivity gains do not deviate significantly from wage cost differentials (see column (3)). In contrast, it appears that productivity is more sensitive to women's level of education than wage costs. More precisely, results show that firms boost their rents (i.e. their value-added wage cost gap) if they substitute low- or middle-educated female workers by high-educated ones. Tertiary educated women are thus found to be underpaid relative to their same-gender co-workers that are less educated (and vice versa). No such discrepancy is found among male workers.

As a robustness test, we re-estimated our model considering a larger number of educational categories (four instead of three) in interaction with workers' gender. Results, reported in Appendix 8, still support the hypothesis that high-educated workers, be they women or men, are more productive and costly than their same-gender lower educated co-workers. As regards potential discrepancies, chi-squared statistics for equality of regression coefficients again suggest that firm-level rents increase significantly when replacing low-educated female workers by more educated ones. They also confirm that no such misalignment is observed for the group of male workers. ${ }^{34,35}$

\section{Conclusions}

This paper estimates the impact of education on hourly productivity, wage costs and the gap between these two variables at the firm level. It significantly contributes to the existing literature as it is one of the first to (1) use a large representative data set (i.e. Belgian linked employer-employee panel data covering most private-sector firms over the period 1999-2010), (2) address important methodological issues such as firm-level fixed effects, endogeneity and state dependence of firm productivity and wages and (3) examine whether education increases productivity and wage costs equally (i.e. to extend the analysis to wage costs and productivity-wage gaps). It also adds to previous research by providing first evidence on whether the alignment between productivity and wage costs across educational levels depends on workers' characteristics, i.e. their age and gender.

Findings, based on the generalised method of moments (GMM) and the Levinsohn and Petrin (2003) estimator, show a robust upward-sloping profile between education and wage costs, on the one hand, and education and productivity, on the other. They also systematically highlight that educational credentials have a stronger impact on productivity than on wage costs. Firms' profitability (i.e. productivity-wage gap) is indeed found to rise when lower educated workers are substituted by higher educated ones (and vice versa). Estimates thus support the existence of a 'wage-compression effect, i.e. a situation in which the distribution of wage costs is more compressed than workers' education-productivity profile. More precisely, they suggest that firm rents increase on average by $1.4 \%(0.6 \%)$ in the long run (short run) if the fraction of higheducated workers within a firm increases by 10 percentage points (and is compensated by a proportional decrease in the share of low-educated workers). Yet, the size of this effect is found to depend crucially on workers' characteristics (i.e. their age and gender). The misalignment between education-driven productivity gains and wage cost 
Table 4 Estimates according to workers' gender, three educational categories

\begin{tabular}{|c|c|c|c|c|}
\hline & \multicolumn{3}{|l|}{ GMM-SYS } & \multirow{2}{*}{$\begin{array}{l}\text { LP } \\
\text { Value added per } \\
\text { hour worked (In) }\end{array}$} \\
\hline & $\begin{array}{l}\text { Value added per } \\
\text { hour worked (In) }\end{array}$ & $\begin{array}{l}\text { Wage cost per } \\
\text { hour worked (In) }\end{array}$ & $\begin{array}{l}\text { Value added-wage } \\
\text { cost gap }{ }^{c}\end{array}$ & \\
\hline & (1) & (2) & (3) & (4) \\
\hline $\begin{array}{l}\text { Lagged } \\
\text { dependent } \\
\text { variable (In) }\end{array}$ & $\begin{array}{l}0.661^{* * *} \\
(0.056)\end{array}$ & $\begin{array}{l}0.453^{* * *} \\
(0.135)\end{array}$ & $\begin{array}{l}0.621^{* * *} \\
(0.045)\end{array}$ & $\begin{array}{l}0.791^{* * *} \\
(0.043)\end{array}$ \\
\hline \multicolumn{5}{|c|}{ Shares of workers ${ }^{a}$} \\
\hline $\begin{array}{l}\text { Male low- } \\
\text { educated } \\
\text { (ME12) }\end{array}$ & Reference & Reference & Reference & Reference \\
\hline $\begin{array}{l}\text { Female low- } \\
\text { educated } \\
\text { (FE12) }\end{array}$ & $\begin{array}{l}-0.029 \\
(0.060)\end{array}$ & $\begin{array}{l}-0.060 \\
(0.049)\end{array}$ & $\begin{array}{l}0.007 \\
(0.046)\end{array}$ & $\begin{array}{l}-0.034 \\
(0.026)\end{array}$ \\
\hline $\begin{array}{l}\text { Male middle- } \\
\text { educated } \\
\text { (ME34) }\end{array}$ & $\begin{array}{l}0.058^{* *} \\
(0.025)\end{array}$ & $\begin{array}{l}0.031^{* *} \\
(0.016)\end{array}$ & $\begin{array}{l}0.029 \\
(0.024)\end{array}$ & $\begin{array}{l}0.009 \\
(0.013)\end{array}$ \\
\hline $\begin{array}{l}\text { Female } \\
\text { middle- } \\
\text { educated } \\
\text { (FE34) }\end{array}$ & $\begin{array}{l}0.014 \\
(0.060)\end{array}$ & $\begin{array}{l}-0.035 \\
(0.041)\end{array}$ & $\begin{array}{l}0.019 \\
(0.043)\end{array}$ & $\begin{array}{l}0.025 \\
(0.020)\end{array}$ \\
\hline $\begin{array}{l}\text { Male high- } \\
\text { educated } \\
\text { (ME567) }\end{array}$ & $\begin{array}{l}0.101^{*} \\
(0.054)\end{array}$ & $\begin{array}{l}0.150^{* * *} \\
(0.050)\end{array}$ & $\begin{array}{l}0.009 \\
(0.045)\end{array}$ & $\begin{array}{l}0.119^{* * *} \\
(0.032)\end{array}$ \\
\hline $\begin{array}{l}\text { Female high- } \\
\text { educated } \\
\text { (FE567) }\end{array}$ & $\begin{array}{l}0.151^{*} \\
(0.077)\end{array}$ & $\begin{array}{l}0.082 \\
(0.069)\end{array}$ & $\begin{array}{l}0.125^{* *} \\
(0.051)\end{array}$ & $\begin{array}{l}0.128^{* * *} \\
(0.039)\end{array}$ \\
\hline $\begin{array}{l}\text { Hansen over- } \\
\text { identification } \\
\text { test, } p \text { value }\end{array}$ & 0.319 & 0.138 & 0.737 & \\
\hline $\begin{array}{l}\text { Arellano-Bond } \\
\text { test for } A R(2), p \\
\text { value }\end{array}$ & 0.129 & 0.338 & 0.215 & \\
\hline $\begin{array}{l}\text { Number of } \\
\text { observations }\end{array}$ & 6714 & 6714 & 6714 & 6691 \\
\hline $\begin{array}{l}\text { Number of } \\
\text { firms }\end{array}$ & 1844 & 1844 & 1844 & 1844 \\
\hline \multicolumn{5}{|c|}{$\begin{array}{l}\text { Chi-squared statistic for equality } \\
\text { of regression coefficients, } H_{0}\end{array}$} \\
\hline $\mathrm{FE} 12=\mathrm{ME} 34$ & 2.36 & $4.10^{* *}$ & 0.25 & $2.71^{*}$ \\
\hline $\mathrm{FE} 12=\mathrm{FE} 34$ & 0.68 & 0.43 & 0.08 & $3.11^{*}$ \\
\hline $\begin{array}{l}\mathrm{FE} 12= \\
\mathrm{ME} 567\end{array}$ & $3.77^{*}$ & $11.30^{* * *}$ & 0.00 & $12.33^{* * *}$ \\
\hline $\mathrm{FE} 12=\mathrm{FE} 567$ & $6.09^{* *}$ & $3.44^{*}$ & $4.96^{* *}$ & $10.76^{* * *}$ \\
\hline ME34 = FE34 & 0.55 & $2.88^{*}$ & 0.06 & 0.58 \\
\hline $\begin{array}{l}\text { ME34 = } \\
\text { ME567 }\end{array}$ & 0.70 & $6.19^{* *}$ & 0.23 & $14.68^{* * *}$ \\
\hline $\begin{array}{l}\text { ME34 = } \\
\text { FE567 }\end{array}$ & 1.42 & 0.54 & $3.68^{*}$ & $9.29^{* * *}$ \\
\hline $\begin{array}{l}\text { FE34 = } \\
\text { ME567 }\end{array}$ & 1.60 & $9.45^{* * *}$ & 0.05 & $10.60^{* * *}$ \\
\hline FE34 = FE567 & $4.35^{* *}$ & 2.57 & $4.51^{* *}$ & $5.38^{* *}$ \\
\hline $\begin{array}{l}\text { ME567 = } \\
\text { FE567 }\end{array}$ & 0.31 & 1.11 & $3.17^{*}$ & 0.05 \\
\hline
\end{tabular}


Table 4 Estimates according to workers' gender, three educational categories (Continued)

\begin{tabular}{|c|c|c|c|c|c|}
\hline & & \multicolumn{3}{|l|}{ GMM-SYS } & \multirow{2}{*}{$\begin{array}{l}\text { LP } \\
\text { Value added per } \\
\text { hour worked (In) }\end{array}$} \\
\hline & & $\begin{array}{l}\text { Value added per } \\
\text { hour worked (In) }\end{array}$ & $\begin{array}{l}\text { Wage cost per } \\
\text { hour worked (In) }\end{array}$ & $\begin{array}{l}\text { Value added-wage } \\
\text { cost gap }{ }^{c}\end{array}$ & \\
\hline & & (1) & $(2)$ & (3) & (4) \\
\hline \multirow{2}{*}{\multicolumn{2}{|c|}{$\begin{array}{l}\text { a) Among } \\
\text { male } \\
\text { workers }\end{array}$}} & $\begin{array}{l}\text { ME12 < ME567 } \\
\text { ME12 < ME34 } \\
\text { but } \\
\text { ME34 = ME567 }\end{array}$ & $\begin{array}{l}\text { ME12<ME567 } \\
\text { ME12<ME34 } \\
\text { ME34 < ME567 }\end{array}$ & $\begin{array}{l}\text { ME12 }=\text { ME567 } \\
\text { ME12 }=\text { ME34 } \\
\text { ME34 }=\text { ME567 }\end{array}$ & $\begin{array}{l}\text { ME12 < ME567 } \\
\text { ME34 < ME567 } \\
\text { but } \\
\text { ME12 = ME34 }\end{array}$ \\
\hline & & $\begin{array}{l}\Rightarrow \text { ME12 significantly } \\
\text { less productive than } \\
\text { ME34 and ME567 }\end{array}$ & $\begin{array}{l}\Rightarrow \text { Education } \\
\text { increases wage } \\
\text { costs significantly }\end{array}$ & $\begin{array}{l}\Rightarrow \text { Education has no } \\
\text { significant impact on } \\
\text { profits }\end{array}$ & $\begin{array}{l}\Rightarrow \text { ME567 significantly } \\
\text { more productive than } \\
\text { ME12 and ME34 }\end{array}$ \\
\hline \multirow[t]{2}{*}{ a) } & $\begin{array}{l}\text { b) Among } \\
\text { female } \\
\text { workers }\end{array}$ & $\begin{array}{l}\text { FE12 < FE567 } \\
\text { FE34 < FE567 } \\
\text { but } \\
\text { FE12 = FE34 }\end{array}$ & $\begin{array}{l}\text { FE12 }<\text { FE567 } \\
\text { but } \\
\text { FE12 = FE34 } \\
\text { FE34 = FE567 }\end{array}$ & $\begin{array}{l}\text { FE12 < FE567 } \\
\text { FE34 < FE567 } \\
\text { but } \\
\text { FE12 = FE34 }\end{array}$ & $\begin{array}{l}\text { FE12 }<\text { FE567 } \\
\text { FE34 }<\text { FE567 } \\
\text { FE12 }<\text { FE34 }\end{array}$ \\
\hline & & $\begin{array}{l}\Rightarrow \text { FE567 significantly } \\
\text { more productive than } \\
\text { FE12 and FE34 }\end{array}$ & $\begin{array}{l}\Rightarrow \text { FE } 567 \\
\text { significantly more } \\
\text { costly than FE12 }\end{array}$ & $\begin{array}{l}\Rightarrow \text { FE567 significantly } \\
\text { more profitable than } \\
\text { FE12 and FE34 }\end{array}$ & $\begin{array}{l}\Rightarrow \text { Education } \\
\text { increases productivity } \\
\text { significantly }\end{array}$ \\
\hline
\end{tabular}

Notes: Standard errors, that are robust to heteroskedasticity and autocorrelation, are reported between parentheses. Regressions also control for: \% of workers with 10 years of tenure or more; \% workers younger than 30 and older than 49 years, respectively; \% women; \% part-time workers; \% blue-collar workers; $\%$ workers with fixed term employment contract; \% apprentices; \% temporary agency workers; In of firm size; In of capital stock per worker; level of collective wage bargaining; region where the firm is located ( 2 dummies); industries (8 dummies), and years dummies (11). AR (2) refers to second-order autocorrelation in first-differenced errors. Models (1) to (3) include first and second lags of explanatory variables (except time dummies) as instruments

${ }^{* * *} p<0.01,{ }^{* *} p<0.05,{ }^{*} p<0.1$

${ }^{a}$ Low-educated workers (E12) have at most a degree of lower secondary school. Middle-educated workers (E34) have at most a degree from upper (general, technical or professional) secondary school. High-educated workers (E567) have a tertiary educational attainment (i.e. at least a Bachelor's or equivalent degree)

$\mathrm{b}^{\prime}<^{\prime}\left({ }^{\prime}={ }^{\prime}\right)$ indicates if regression coefficients are (not) statistically different at the $10 \%$ level

${ }^{\mathrm{C}}$ Value added-wage cost gap $=\ln$ (value added per hour) $-\ln$ (wage cost per hour)

differentials appears to be only verified among young workers. Put differently, results suggest that high-educated (low-educated) workers are no longer under-paid (overpaid) when they become older. Findings are also quite different according to gender. Results show that the level of education of women has a significantly stronger positive effect on their productivity than on their wage costs. Highly educated women are thus found to be under-paid relative to their same-gender co-workers who are less educated (and vice versa). In contrast, for male workers, education-driven productivity gains are not found to deviate significantly from wage cost differentials.

How can these findings be interpreted? Results from our baseline specification showing the existence of a 'wage-compression effect' partially back up the predictions of human capital theory. On the one hand, they corroborate the idea that education develops skills that make workers more productive and that wages reflect differences in productivity. On the other, they do not support the hypothesis that education-driven productivity gains are well aligned with wage differentials. Our findings are also not in line with theories (based on tournaments, internal decision-making processes of organisations or monitoring issues) ${ }^{36,37}$ suggesting that high-educated workers are overpaid relative to their respective output elasticities. Estimates are actually more compatible with the literature on social norms and the hysteresis of the wage structure, ${ }^{38}$ fairness theories ${ }^{39}$ and especially arguments according to which labour market regulations-such as minimum wages, collective bargaining and unemployment benefits-increase the reservation wage, especially for workers at the bottom of the wage distribution, and reduce wage inequalities by pushing earnings of low-wage workers upwards (Cahuc and Zylberberg 2014). 
Results according to workers' age can be understood through additional hypothesis testing. Estimates, based on our benchmark regression (see Table 3), suggest that the education-driven wage cost differential is smaller among young workers than among older workers ( $\mathrm{z}$-statistic $=-2.48$ and $p$ value $=0.01$ ), while the contribution of education to firm's value added is not found to be statistically different across age groups $(\mathrm{z}$-statistics $=-0.58$ and $p$ value $=0.56) .{ }^{40,41}$ The observation that the wage cost differential between high- and low-educated workers increases with workers' age can be explained by the fact that white-collar workers in Belgium are much more likely to be paid according to seniority than their blue-collar counterparts (which are typically less educated); this is arguably a result of separate collective agreements for blue- and white-collar workers and more widespread use of seniority-related pay scales in the agreements covering the latter (for more details see, e.g. Kampelmann and Rycx 2013). As a result, seniority-pay profiles are generally much steeper for high- than loweducated workers. A complementary explanation is that labour market regulations essentially affect the lower end of the wage distribution. Hence, they are more likely to compress the wage cost differential between low- and high-educated workers when they are young. ${ }^{42}$ Overall, results thus suggest that high-educated (low-educated) workers are no longer under-paid (over-paid) when they become older because their wage cost to productivity ratio increases at a faster (slower) pace during their career than that of low-educated (high-educated) workers. ${ }^{43}$

Estimates by gender suggest that the over-payment (under-payment) of low-educated (high-educated) workers only holds for women. This finding may be explained by the fact that women are over-represented among low-wage earners and are thus more likely to have their working conditions influenced by labour market regulations. However, the stronger wage-compression effect among women might also result from discrimination and the existence of a glass-ceiling effect, i.e. the fact that women face invisible but real barriers preventing them from obtaining higher-level positions. Indeed, results of Kampelmann and Rycx (2012) show that the occupation-pay profile in Belgian is steeper than the occupation-productivity profile. Accordingly, the fact that women are less likely to hold jobs at the upper rungs of the corporate ladder should ceteris paribus have a stronger detrimental effect on their pay than on their productivity.

Our finding that high-educated women are underpaid could thus be explained by the fact that education raises women's productivity but only weakly raises their wages since a glass ceiling is stopping them from reaching top positions. A complementary argument, provided by Card et al. (2016: 1), is that high-educated women, in a given occupation, 'are less likely to initiate wage bargaining with their employer and are (often) less effective negotiators than men'. These interpretations echo the estimates of Garnero et al. (2014). The latter show that women generate employer rents in the Belgian private sector and that these rents derive from the fact that women earn less than men at any given level of productivity, i.e. are discriminated against.

To sum up, our results show that firms located in Belgium face financial disincentives to employ low-educated workers, especially when they are young. We indeed find that firms employing a larger share of young low-educated workers tend to be less profitable. Policies aiming to improve the labour market prospects of young low-educated workers should thus try to boost their productivity and/or to decrease their wage cost. 
A substantial number of policies (i.e. training programmes, wage subsidies, reductions of social security contributions) are already implemented in Belgium to reach this goal. Yet, our findings suggest that these efforts should be continued and intensified (alongside policies fostering total employment). Furthermore, results show that the wagecompression effect only holds for women. This finding suggests that particular attention should be devoted to the productivity to wage cost ratio of low-educated women but also to policies favouring gender equality in terms of remuneration and career advancement.

\section{Endnotes}

${ }^{1}$ At the macro level, some studies suggest that education fosters output per worker and income per capita (Krueger and Lindahl 2001). However, the use of cross-country panel data over long periods makes the identification of the causal relationship between education and productivity difficult. In particular, controlling for reverse causality (i.e. for the fact that countries with higher growth rates invest more in education) remains challenging (Sianesi and Van Reenen 2003).

${ }^{2}$ Much more effort has actually been devoted to understand the productivity consequences of other workforce characteristics such as age, gender, part-time or temporary contracts (see e.g. Cardoso et al. 2011; Garnero et al. 2014; Giuliano et al. 2017; Devicienti et al. 2017; Göbel and Zwick 2012; Hellerstein et al. 1999a; Nielen and Schiersch 2014; van Ours and Stoeldraijer 2011).

${ }^{3}$ For a detailed description of how some of the prominent theories on mismatches between productivity and wages can be adapted to account for workers' educational heterogeneity, see Rycx et al. (2015).

${ }^{4} \mathrm{We}$ also show results of a more structural approach suggested by Levinsohn and Petrin (2003). For more details, see section 2.3.

${ }^{5}$ Figures for the OECD area show a very similar pattern (OECD 2015). For example, the unemployment rate among the low-educated is more than two times bigger than among tertiary educated workers (i.e. 13.5 and 5.3\% in 2013). Moreover, the employment rate is almost 30 percentage points higher among tertiary educated people than among low-educated ones (i.e. 83.1 and $54.9 \%$ in 2013).

${ }^{6}$ For evidence on workforce over-education/qualification, see e.g. McGuinness (2006) or Montt (2017).

${ }^{7}$ This is estimated through the 'perpetual inventory method' (or PIM, see e.g. OECD (2009) for more details). The PIM incorporates the idea that the capital stock results from investment flows and corrects for capital depreciation and efficiency losses. Following standard practice, we assume a 5\% annual rate of depreciation.

${ }^{8}$ This variable indicates whether wages in the firm are collectively negotiated at the firm level (in addition to national and/or sectoral collective wage agreements that are the norm in Belgium).

${ }^{9}$ All independent variables are measured in terms of shares in total work hours. For instance, the fraction of part-time workers is computed on the basis of the proportion of hours worked by employees working less than $30 \mathrm{~h}$ per week over the total amount of hours worked with the firm. The control variables that have been included in our regressions are in line with the existing literature (for a review of the set of covariates that should be included in this type of analysis see e.g. Göbel and Zwick 2012). As 
highlighted by Mahlberg et al. (2013: 10): 'by including a rather broad set of independent variables, we account for heterogeneity among firms, in order to mitigate the bias that could be caused by omitted variables'.

${ }^{10}$ Expected biases associated with OLS and the relatively poor performance and shortcomings of the FE estimator in the context of firm-level productivity regressions are reviewed in Van Beveren (2012).

${ }^{11}$ We have performed such a test by using a 2SLS estimator on an equation in levels in which our variables of interest are instrumented by first differences. All three equations (i.e. value added, wage costs and gap) pass standard underidentification and weak identification tests. This means that the endogeneity test for the educational variables is valid. This test suggests that for all three equations we have to reject the null hypothesis that educational variables can actually be treated as exogenous

${ }^{12} \mathrm{By}$ 'educational variables', we mean shares of workers by educational level and other input factors.

${ }^{13}$ Bond and Söderbom (2005) provide a review of the literature regarding the identification of production functions. The authors notably highlight that adjustment costs of labour and capital can justify the use of lagged values (of endogenous variables) as instruments.

${ }^{14}$ In the case of our data, the lags we used in the estimator do not correspond exactly to a yearly lag; this is due to the fact that the dependent variables are measured in year $t$ whereas the independent variables are measured in October of year $t-1$. See the presentation of data in Section 3.

${ }^{15}$ Yet, as a robustness test, we also estimated Eqs. (1) to (3) with a static GMM-SYS estimator. Our main findings remain unaffected using this alternative estimator (see Appendix 5).

${ }^{16}$ It thus covers the following sectors: (i) mining and quarrying (C), (ii) manufacturing (D), (iii) electricity, gas and water supply (E), (iv) construction (F), (v) wholesale and retail trade, repair of motor vehicles, motorcycles and personal and household goods (G), (vi) hotels and restaurants (H), (vii) transport, storage and communication (I), (viii) financial intermediation (J), and ix) real estate, renting and business activities (K).

${ }^{17}$ The SES is a stratified sample. For details on stratification criteria see Appendix 10.

${ }^{18}$ For instance, we eliminate a (very small) number of firms for which the recorded value added was negative.

${ }^{19}$ This restriction is unlikely to affect our results as it leads to a very small drop in sample size. The average number of observations per firm in each year is equal to 37 in our final sample.

${ }^{20} \mathrm{All}$ variables measured in monetary terms have been deflated to constant prices of 2004 by the consumer price index taken from Statistics Belgium.

${ }^{21}$ OLS estimates (using respectively 3 and 7 educational categories) are reported in Appendices 1 and 2.

${ }^{22}$ As noted in Section 2.1, this variable is measured by the value added-wage cost gap, i.e. the difference between log hourly value added and log hourly wage costs.

${ }^{23}$ Note that lagged dependent variables are always found to be highly significant in our regressions. In line with the existing literature (see Section 2.1), they confirm that productivity, wage costs and profitability are highly persistent at the firm level. Moreover, GMM coefficients on lagged dependent variables fall systematically between the OLS and FE estimates (available on request). As highlighted by Roodman (2009), this result supports the appropriateness of our dynamic GMM-SYS specification. 
${ }^{24}$ First and second lags of explanatory variables (except time dummies) are used as instruments.

${ }^{25}$ We also tested for weak instruments by computing the Kleibergen-Paap rk Wald F statistic (van Ours and Stoeldraijer 2011). Given that this test is not applicable in a GMM-SYS specification, we used a GMM specification in first differences in which the first-differenced shares of education variables were instrumented by their lagged levels (in $t-1$ and $t-2$ ). We reject the null hypothesis of weak instruments for all models presented in this paper, including the models that differentiate education groups by age and gender.

${ }^{26} \mathrm{On}$ the basis of a chi-squared test for equality of regression coefficients.

${ }^{27}$ The exclusion of firm size among covariates does not affect our conclusions (results available on request).

${ }^{28}$ Note that regression coefficients obtained through a dynamic specification correspond to short-run effects. To obtain the long-run impact of changes in educational shares on productivity, wage costs and profits, Koyck (1954) has shown that estimates reported in Table 2 should be divided by 1 minus the coefficient associated to the lagged dependent variable. Applying this transformation to our benchmark results, we find that elasticities are approximately two times bigger in the long run than in the short run.

${ }^{29}$ As a robustness test, we re-estimated our benchmark model (i.e. Eqs. (1) to (3)) adding among explanatory variables: (a) the squared values of capital and educational variables, (b) the cross-product between capital and educational variables, (c) the cross-product between educational variables. Put differently, we adopted a translog specification. Estimates, reported in Appendix 3, confirm that education has a positive impact on productivity and on wage costs (see columns (1) and (2)). However, the inclusion of interaction terms and squared values of capital and educational variables increases the standard errors of our estimates. Yet, they remain qualitatively similar to those obtained with our benchmark specification (see Table 2). Estimates using the productivity-wage gap as dependent variable are reported in column (3). They confirm that firm rents (i.e. productivity-wage gaps) increase significantly when low-educated workers are substituted by high-educated ones. Indeed, estimates show that the productivity-pay gap rises on average by $1.5 \%$ following a 10 percentage point increase in the share of high-educated workers (at the expense of lower educated ones).

${ }^{30}$ We differentiated workers according to whether they had (i) at most primary education, (ii) lower or upper secondary education, (iii) a Bachelor's or equivalent degree and (iv) at least a Master's or equivalent degree. In comparison to our benchmark model, this specification focuses on very low-educated workers and distinguishes between workers with first- and advanced-level tertiary education.

${ }^{31}$ Note that results (see Appendix 5) based on a static GMM-SYS estimator leave our conclusions unaffected. Yet, as expected (see footnote 28), the size of regression coefficients is found to be larger than in dynamic specifications.

${ }^{32}$ As can be seen from columns (1) to (3) of Appendix 6, this age limit generates a quite balanced distribution of observations across education-age groups. Nevertheless, we also tested the robustness of our estimates fixing the threshold at 50 years. Vandenberghe et al. (2013) indeed suggest that the pay-productivity gap is reversed at a higher age (which they identify at 56). Results based on the 50 years threshold (available on request) corroborate our conclusions. 
${ }^{33}$ The positive relationship between older workers' educational attainment and firm productivity is only significant at the $12 \%$ probability level in the GMM-SYS specification.

${ }^{34}$ Note that men and women have approximately the same age in our sample (respectively, 39.5 and 37.6 years with a standard deviation equal to 10.4 and 10.1). The fact that our results are significantly more pronounced for women than for men does hence not appear to derive from differences in the latter's age.

${ }^{35}$ We also re-estimated our benchmark equations separately for firms operating respectively in the industry and services. Results (reported in Rycx et al. 2015) corroborate findings for the overall sample of firms. Indeed, for both sectors, they highlight that (a) workers' educational credentials raise productivity and wage costs and (b) high-educated workers are underpaid (i.e. increase firm profits) with respect to their low-educated counterparts.

${ }^{36}$ Tournament theory predicts a convex relationship between a worker's pay and his position in the firm's hierarchy, to the extent that workers at the top of the hierarchy receive wages beyond their marginal products. Given that low-educated workers are generally found at the bottom of corporate hierarchies, this theory suggests that firm-level profits should increase with the share of low-educated workers (Lazear and Rosen 1981).

${ }^{37}$ The theory put forward by Osterman et al. (2009: 705) suggests that any rent generated by the firm is unequally distributed among educational groups. Moreover, the analysis of principal-agent problems suggests that wages of higher educated workers might be higher than predicted by standard competitive theory (Bebchuk and Fried 2003).

${ }^{38}$ Given that technological change over the past decades appears to be skill/task biased and that low-educated workers are typically less skilled and often doing more routine tasks (Goos et al. 2014), the hysteresis in social norms discussed by Doeringer and Piore (1985) and Skott (2005) could lead to the overpayment of low-educated workers whose productivity might have been negatively affected by technological change, and the underpayment of high-educated workers whose productivity might have increased.

${ }^{39}$ Following Hamermesh (1975) and Akerlof and Yellen (1988), there is an efficiency argument in paying high-productivity jobs in a firm below and low-productivity jobs above their marginal products so as to compress the overall wage structure.

${ }^{40}$ These results are obtained with the 'lincom' command in STATA, after estimating the same regressions as in Table 4 but using as reference category young middle-educated workers' (i.e. YE34). The exact syntax is as follows: lincom YE567 - YE12 - OE567 + OE12.

${ }^{41} \mathrm{We}$ do not reject the hypothesis that the education-driven productivity differential may decrease among older cohorts of workers, notably among 50+ workers. Yet, it is difficult to provide consistent evidence on this as the number of observations within each education-age group decreases quite substantially when moving the age threshold from 40 to 50 years.

${ }^{42}$ It should, however, be borne in mind that 'education' is not perfectly constant over time since the different age groups in our sample obtained their educational credentials at different moments in time. These credentials could therefore reflect different types of skills across generations that attended school at different moments in time (for a more complete discussion of the underlying issue, see e.g. Cataldi et al. (2011)).

${ }^{43}$ Our estimates are also compatible with the employer learning literature (see e.g. Altonji and Pierret 2001). The intuition is as follows: as workers become older there is more and more information available to assess their true productivity and hence it becomes easier to set wages that align well with their productivity. 


\section{Appendix 1}

Table 5 OLS (static and dynamic) estimates for the entire sample, three educational categories

\begin{tabular}{|c|c|c|c|c|c|c|}
\hline & \multicolumn{2}{|c|}{$\begin{array}{l}\text { Value added per } \\
\text { hour worked (In) }\end{array}$} & \multicolumn{2}{|l|}{$\begin{array}{l}\text { Wage cost per } \\
\text { hour worked (In) }\end{array}$} & \multicolumn{2}{|c|}{$\begin{array}{l}\text { Value added-wage } \\
\text { cost gap }{ }^{c}\end{array}$} \\
\hline & (1) & (2) & (3) & (4) & $\overline{(5)}$ & (6) \\
\hline $\begin{array}{l}\text { Lagged dependent } \\
\text { variable (In) }\end{array}$ & & $\begin{array}{l}0.839^{* * *} \\
(0.038)\end{array}$ & & $\begin{array}{l}0.765^{* * *} \\
(0.099)\end{array}$ & & $\begin{array}{l}0.839^{* * *} \\
(0.026)\end{array}$ \\
\hline \multicolumn{7}{|l|}{ Shares of workers ${ }^{a}$} \\
\hline $\begin{array}{l}\text { Low- } \\
\text { educated } \\
\text { (E12) }\end{array}$ & Reference & Reference & Reference & Reference & Reference & Reference \\
\hline $\begin{array}{l}\text { Middle- } \\
\text { educated } \\
\text { (E34) }\end{array}$ & $\begin{array}{l}0.051^{* * *} \\
(0.018)\end{array}$ & $\begin{array}{l}0.020^{* * *} \\
(0.010)\end{array}$ & $\begin{array}{l}0.036^{* * *} \\
(0.010)\end{array}$ & $\begin{array}{l}0.010^{*} \\
(0.006)\end{array}$ & $\begin{array}{l}0.015 \\
(0.014)\end{array}$ & $\begin{array}{l}0.011 \\
(0.010)\end{array}$ \\
\hline $\begin{array}{l}\text { Highly } \\
\text { educated } \\
\text { (E567) }\end{array}$ & $\begin{array}{l}0.752^{* * *} \\
(0.038)\end{array}$ & $\begin{array}{l}0.131^{* * *} \\
(0.030)\end{array}$ & $\begin{array}{l}0.564^{* * *} \\
(0.023)\end{array}$ & $\begin{array}{l}0.130^{* *} \\
(0.053)\end{array}$ & $\begin{array}{l}0.188^{* * *} \\
(0.028)\end{array}$ & $\begin{array}{l}0.044^{* * *} \\
(0.016)\end{array}$ \\
\hline R-squared & 0.431 & 0.841 & 0.517 & 0.819 & 0.232 & 0.748 \\
\hline $\begin{array}{l}\text { F-stat (joint significance), } p \\
\text { value }\end{array}$ & 0.00 & 0.00 & 0.00 & 0.00 & 0.00 & 0.00 \\
\hline Number of observations & 6714 & 6714 & 6714 & 6714 & 6714 & 6714 \\
\hline Number of firms & 1844 & 1844 & 1844 & 1844 & 1844 & 1844 \\
\hline \multicolumn{7}{|l|}{$\begin{array}{l}\text { F-statistic for equality } \\
\text { of regression coefficients, } \mathrm{H}_{0}\end{array}$} \\
\hline $\mathrm{E} 34=\mathrm{E} 567$ & $203.58^{* * *}$ & $9.71^{* * *}$ & $291.16^{* * *}$ & $3.09^{* *}$ & $42.92^{* * *}$ & $6.64^{* * *}$ \\
\hline \multirow[t]{2}{*}{ Interpretation ${ }^{\mathrm{b}}$} & $\begin{array}{l}\text { E12<E34 } \\
\text { E12<E567 } \\
\text { E34 <E567 }\end{array}$ & $\begin{array}{l}\text { E12<E34 } \\
\text { E12<E567 } \\
\text { E34 <E567 }\end{array}$ & $\begin{array}{l}E 12<E 34 \\
E 12<E 567 \\
E 34<E 567\end{array}$ & $\begin{array}{l}E 12<E 34 \\
E 12<E 567 \\
E 34<E 567\end{array}$ & $\begin{array}{l}E 12< \\
\text { E567 } \\
\text { E34< } \\
\text { E567 }\end{array}$ & $\begin{array}{l}\text { E12< } \\
\text { E567 } \\
\text { E34< } \\
\text { E567 }\end{array}$ \\
\hline & $\begin{array}{l}\Rightarrow \text { Education } \\
\text { increases } \\
\text { productivity }\end{array}$ & $\begin{array}{l}\Rightarrow \text { Education } \\
\text { increases } \\
\text { productivity }\end{array}$ & $\begin{array}{l}\Rightarrow \text { Education } \\
\text { increases wage } \\
\text { costs }\end{array}$ & $\begin{array}{l}\Rightarrow \text { Education } \\
\text { increases wage } \\
\text { costs }\end{array}$ & $\begin{array}{l}\Rightarrow \text { E567 } \\
\text { more } \\
\text { profitable } \\
\text { than E12 } \\
\text { and E34 }\end{array}$ & $\begin{array}{l}\Rightarrow \text { E567 } \\
\text { more } \\
\text { profitable } \\
\text { than E12 } \\
\text { and E34 }\end{array}$ \\
\hline
\end{tabular}

Notes: Standard errors, that are robust to heteroskedasticity and autocorrelation, are reported between parentheses. Regressions also control for: \% of workers with 10 years of tenure or more; \% workers younger than 30 and older than 49 years, respectively; \% women; $\%$ part-time workers; $\%$ blue-collar workers; $\%$ workers with fixed term employment contract; \% apprentices; \% temporary agency workers; In of firm size; In of capital stock per worker; level of collective wage bargaining; region where the firm is located ( 2 dummies); industries ( 8 dummies), and years dummies (11)

${ }^{* * *} p<0.01,{ }^{* *} p<0.05,{ }^{*} p<0.1$

a Low-educated workers (E12) have at most a degree of lower secondary school. Middle-educated workers (E34) have at most a degree from upper (general, technical or professional) secondary school. High-educated workers (E567) have a tertiary educational attainment (i.e. at least a Bachelor's or equivalent degree)

$\mathrm{b}^{\prime}<{ }^{\prime}$ ' indicates when regression coefficients are statistically different at the $10 \%$ level

c Value added-wage cost gap $=\ln$ (value added per hour) $-\ln$ (wage cost per hour) 


\section{Appendix 2}

Table 6 OLS (static and dynamic) estimates for the entire sample, seven educational categories

\begin{tabular}{|c|c|c|c|c|c|c|}
\hline & \multicolumn{2}{|c|}{$\begin{array}{l}\text { Value added per } \\
\text { hour worked (In) }\end{array}$} & \multicolumn{2}{|c|}{$\begin{array}{l}\text { Wage cost per } \\
\text { hour worked (In) }\end{array}$} & \multicolumn{2}{|c|}{$\begin{array}{l}\text { Value added-wage } \\
\text { cost gap }{ }^{\mathrm{b}}\end{array}$} \\
\hline & (1) & $(2)$ & (3) & (4) & $(5)$ & (6) \\
\hline $\begin{array}{l}\text { Lagged dependent variable } \\
(\mathrm{In})\end{array}$ & & $\begin{array}{l}0.835^{* * *} \\
(0.039)\end{array}$ & & $\begin{array}{l}0.757^{* * *} \\
(0.101)\end{array}$ & & $\begin{array}{l}0.838^{* * *} \\
(0.026)\end{array}$ \\
\hline \multicolumn{7}{|l|}{ Shares of workers } \\
\hline $\begin{array}{l}\text { Primary education } \\
\text { (E1) }\end{array}$ & Reference & Reference & Reference & Reference & Reference & Reference \\
\hline $\begin{array}{l}\text { Lower secondary } \\
(\mathrm{E} 2)\end{array}$ & $\begin{array}{l}-0.002 \\
(0.026)\end{array}$ & $\begin{array}{l}0.001 \\
(0.015)\end{array}$ & $\begin{array}{l}-0.027 \\
(0.017)\end{array}$ & $\begin{array}{l}-0.004 \\
(0.009)\end{array}$ & $\begin{array}{l}0.025 \\
(0.020)\end{array}$ & $\begin{array}{l}0.003 \\
(0.014)\end{array}$ \\
\hline $\begin{array}{l}\text { General upper } \\
\text { secondary education } \\
\text { (E3) }\end{array}$ & $\begin{array}{l}0.084^{* * * *} \\
(0.029)\end{array}$ & $\begin{array}{l}0.036^{* *} \\
(0.015)\end{array}$ & $\begin{array}{l}0.021 \\
(0.017)\end{array}$ & $\begin{array}{l}0.008 \\
(0.009)\end{array}$ & $\begin{array}{l}0.062^{* * *} \\
(0.022)\end{array}$ & $\begin{array}{l}0.029^{* *} \\
(0.013)\end{array}$ \\
\hline $\begin{array}{l}\text { Technical and } \\
\text { professional upper } \\
\text { secondary education } \\
\text { (E4) }\end{array}$ & $\begin{array}{l}0.039 \\
(0.028)\end{array}$ & $\begin{array}{l}0.012 \\
(0.014)\end{array}$ & $\begin{array}{l}0.023 \\
(0.017)\end{array}$ & $\begin{array}{l}0.010 \\
(0.009)\end{array}$ & $\begin{array}{l}0.016 \\
(0.021)\end{array}$ & $\begin{array}{l}0.003 \\
(0.012)\end{array}$ \\
\hline $\begin{array}{l}\text { Bachelor's or } \\
\text { equivalent level (E5) }\end{array}$ & $\begin{array}{l}0.483^{* * *} \\
(0.049)\end{array}$ & $\begin{array}{l}0.078^{* * *} \\
(0.028)\end{array}$ & $\begin{array}{l}0.338^{* * *} \\
(0.031)\end{array}$ & $\begin{array}{l}0.075^{* *} \\
(0.036)\end{array}$ & $\begin{array}{l}0.142^{* * *} \\
(0.036)\end{array}$ & $\begin{array}{l}0.027 \\
(0.020)\end{array}$ \\
\hline $\begin{array}{l}\text { Master's or } \\
\text { equivalent level (E6) }\end{array}$ & $\begin{array}{l}0.993^{* * *} \\
(0.065)\end{array}$ & $\begin{array}{l}0.200^{* * *} \\
(0.043)\end{array}$ & $\begin{array}{l}0.736^{* * *} \\
(0.038)\end{array}$ & $\begin{array}{l}0.186^{* * *} \\
(0.072)\end{array}$ & $\begin{array}{l}0.263^{* * *} \\
(0.050)\end{array}$ & $\begin{array}{l}0.076^{* * *} \\
(0.023)\end{array}$ \\
\hline $\begin{array}{l}\text { Post-Master's level or } \\
\text { PhD (E7) }\end{array}$ & $\begin{array}{l}2.265^{* * *} \\
(0.410)\end{array}$ & $\begin{array}{l}0.338^{* *} \\
(0.155)\end{array}$ & $\begin{array}{l}1.391^{* * *} \\
(0.229)\end{array}$ & $\begin{array}{l}0.317^{* *} \\
(0.160)\end{array}$ & $\begin{array}{l}0.859^{* * *} \\
(0.301)\end{array}$ & $\begin{array}{l}0.118 \\
(0.120)\end{array}$ \\
\hline R-squared & 0.444 & 0.841 & 0.534 & 0.820 & 0.236 & 0.748 \\
\hline $\begin{array}{l}\text { F-stat (joint significance), } \\
p \text { value }\end{array}$ & 0.00 & 0.00 & 0.00 & 0.00 & 0.00 & 0.00 \\
\hline Number of observations & 6714 & 6714 & 6714 & 6714 & 6714 & 6714 \\
\hline Number of firms & 1844 & 1844 & 1844 & 1844 & 1844 & 1844 \\
\hline \multicolumn{7}{|l|}{$\begin{array}{l}\text { F-statistic for equality of } \\
\text { regression coefficients, } H_{0}\end{array}$} \\
\hline $\mathrm{E} 2=\mathrm{E} 3$ & $13.72^{* * *}$ & $5.97^{* *}$ & $13.46^{* * *}$ & 1.71 & $3.96^{* *}$ & $3.81^{*}$ \\
\hline$E 2=E 4$ & $3.44^{*}$ & 0.70 & $15.04^{* * *}$ & $3.36^{*}$ & 0.25 & 0.00 \\
\hline $\mathrm{E} 2=\mathrm{E} 5$ & $110.22^{* * *}$ & $7.84^{* * *}$ & $163.88^{* * *}$ & $4.47^{*}$ & $12.13^{* * *}$ & 1.57 \\
\hline$E 2=E 6$ & $252.80^{* * *}$ & $21.66^{* * *}$ & $455.08^{* * *}$ & $6.58^{* *}$ & $23.56^{* * *}$ & $8.51^{* * *}$ \\
\hline $\mathrm{E} 2=\mathrm{E} 7$ & $30.62^{* * *}$ & $4.73^{* *}$ & $38.16^{* * *}$ & $3.94^{* *}$ & $7.71^{* * *}$ & 0.90 \\
\hline $\mathrm{E} 3=\mathrm{E} 4$ & $3.76^{*}$ & $3.70^{*}$ & 0.01 & 0.05 & $7.04^{* * *}$ & $6.35^{* *}$ \\
\hline $\mathrm{E} 3=\mathrm{E} 5$ & $70.57^{* * *}$ & $2.83^{*}$ & $118.04^{* * *}$ & $4.21^{* *}$ & $5.21^{* *}$ & 0.02 \\
\hline $\mathrm{E} 3=\mathrm{E} 6$ & $216.98^{* * *}$ & $17.61^{* * *}$ & $396.86^{* * *}$ & $6.64^{* * *}$ & $18.27^{* * *}$ & $4.87^{* *}$ \\
\hline $\mathrm{E} 3=\mathrm{E} 7$ & $28.60^{* * *}$ & $3.95^{* *}$ & $35.86^{* * *}$ & $3.88^{* *}$ & $7.12^{* * *}$ & 0.56 \\
\hline $\mathrm{E} 4=\mathrm{E} 5$ & $85.27^{* * *}$ & $6.10^{* *}$ & $109.90^{* * *}$ & $3.54^{*}$ & $13.07^{* * *}$ & 1.62 \\
\hline $\mathrm{E} 4=\mathrm{E} 6$ & $232.89^{* * *}$ & $20.83^{* * *}$ & $371.83^{* * *}$ & $6.17^{*}$ & $27.99^{* * *}$ & $11.75^{* * *}$ \\
\hline $\mathrm{E} 4=\mathrm{E} 7$ & $29.64^{* * *}$ & $4.51^{* *}$ & $35.40^{* * *}$ & $3.74^{*}$ & $7.98^{* * *}$ & 0.94 \\
\hline $\mathrm{E} 5=\mathrm{E} 6$ & $41.66^{* * *}$ & $11.21^{* * *}$ & $88.24^{* * *}$ & $6.63^{* * *}$ & $3.83^{*}$ & $2.97^{*}$ \\
\hline $\mathrm{E} 5=\mathrm{E} 7$ & $18.22^{* * *}$ & $2.96^{*}$ & $20.46^{* * *}$ & $3.35^{*}$ & $5.43^{* *}$ & 0.54 \\
\hline$E 6=E 7$ & $9.51^{* * *}$ & 0.91 & $7.58^{* * *}$ & 1.47 & $4.15^{* *}$ & 0.13 \\
\hline Interpretation ${ }^{a}$ & $\begin{array}{l}E 1< \\
E(3,5,6,7) \\
E 2< \\
E(3,4,5,6,7) \\
E 3<E(4,5,6)\end{array}$ & $\begin{array}{l}E 1< \\
E(3,5,6,7) \\
E 2< \\
E(3,5,6,7)\end{array}$ & $\begin{array}{l}E 1<E(5,6,7) \\
E 2< \\
E(3,4,5,6,7) \\
E 3<E(5,6,7) \\
E 4<E(6,7)\end{array}$ & $\begin{array}{l}E 1<E(5,6,7) \\
E 2< \\
E(4,5,6,7) \\
E 3<E(5,6,7) \\
E 4<E(5,6,7)\end{array}$ & $\begin{array}{l}E 1< \\
E(3,5,6,7) \\
E 2< \\
E(3,5,6,7)\end{array}$ & $\begin{array}{l}\mathrm{E} 1<\mathrm{E}(3,6) \\
\mathrm{E} 2<\mathrm{E}(3,6) \\
\mathrm{E} 3<\mathrm{E}(4,6) \\
\mathrm{E} 4<\mathrm{E} 6 \\
\mathrm{E} 5<\mathrm{E} 6\end{array}$ \\
\hline
\end{tabular}


Table 6 OLS (static and dynamic) estimates for the entire sample, seven educational categories (Continued)

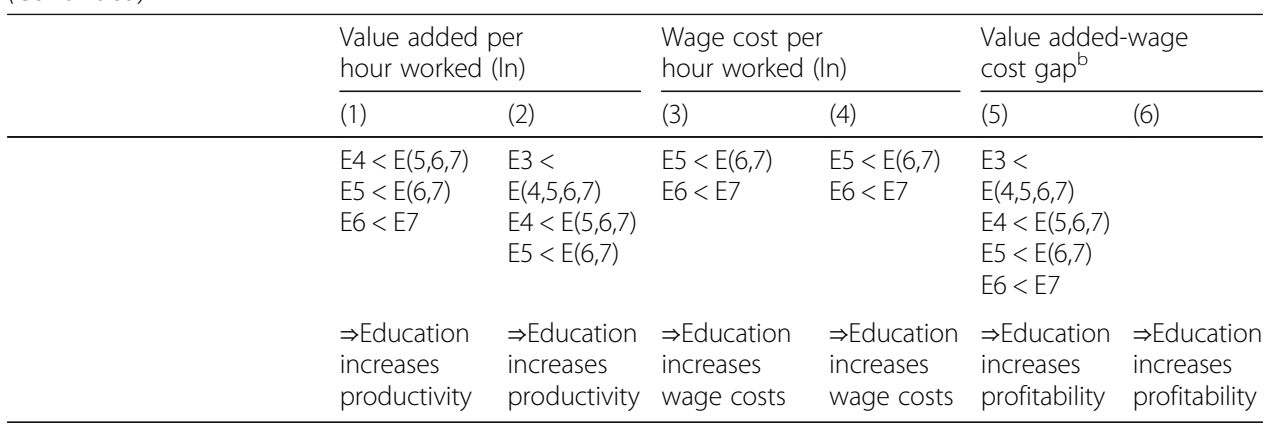

Notes: Standard errors, that are robust to heteroskedasticity and autocorrelation, are reported between parentheses. Regressions also control for: \% of workers with 10 years of tenure or more; \% workers younger than 30 and older than 49 years, respectively; \% women; \% part-time workers; \% blue-collar workers; \% workers with fixed term employment contract; \% apprentices; \% temporary agency workers; In of firm size; In of capital stock per worker; level of collective wage bargaining; region where the firm is located ( 2 dummies); industries ( 8 dummies), and years dummies (11) ${ }^{* * *} p<0.01,{ }^{* *} p<0.05,{ }^{*} p<0.1$

a ' $<$ ' indicates when regression coefficients are statistically different at the $10 \%$ level

${ }^{\mathrm{b}}$ Value added-wage cost gap $=\ln$ (value added per hour) $-\ln$ (wage cost per hour) 


\section{Appendix 3}

Table 7 Estimates for the entire sample, three educational categories, translog specification

\begin{tabular}{|c|c|c|c|}
\hline & \multicolumn{3}{|l|}{ GMM-SYS } \\
\hline & $\begin{array}{l}\text { Value added per } \\
\text { hour worked (In) }\end{array}$ & $\begin{array}{l}\text { Wage cost per } \\
\text { hour worked (In) }\end{array}$ & $\begin{array}{l}\text { Value added-wage } \\
\text { cost gap }{ }^{c}\end{array}$ \\
\hline & (1) & (2) & (3) \\
\hline $\begin{array}{l}\text { Lagged dependent variable } \\
(\ln )\end{array}$ & $\begin{array}{l}0.852^{* * *} \\
(0.020)\end{array}$ & $\begin{array}{l}0.781^{* * *} \\
(0.040)\end{array}$ & $\begin{array}{l}0.671^{* * *} \\
(0.036)\end{array}$ \\
\hline \multicolumn{4}{|l|}{ Shares of worker ${ }^{a}$} \\
\hline Low-educated (E12) & Reference & Reference & Reference \\
\hline Middle-educated (E34) & $\begin{array}{l}0.067 \\
(0.180)\end{array}$ & $\begin{array}{l}0.070 \\
(0.015)\end{array}$ & $\begin{array}{l}-0.021 \\
(0.064)\end{array}$ \\
\hline High-educated (E567) & $\begin{array}{l}0.346 \\
(0.232)\end{array}$ & $\begin{array}{l}0.158 \\
(0.138)\end{array}$ & $\begin{array}{l}0.150^{*} \\
(0.087)\end{array}$ \\
\hline In capital $^{d}$ & $\begin{array}{l}0.024 \\
(0.040)\end{array}$ & $\begin{array}{l}0.030 \\
(0.027)\end{array}$ & $\begin{array}{l}-0.095^{* * *} \\
(0.002)\end{array}$ \\
\hline In capital × In capital & $\begin{array}{l}0.000 \\
(0.002)\end{array}$ & $\begin{array}{l}-0.001 \\
(0.001)\end{array}$ & $\begin{array}{l}0.006^{* * *} \\
(0.002)\end{array}$ \\
\hline In capital × E34 & $\begin{array}{l}-0.000 \\
(0.000)\end{array}$ & $\begin{array}{l}0.000^{*} \\
(0.000)\end{array}$ & $\begin{array}{l}-0.000 \\
(0.000)\end{array}$ \\
\hline In capital × E567 & $\begin{array}{l}0.000 \\
(0.000)\end{array}$ & $\begin{array}{l}-0.000^{*} \\
(0.000)\end{array}$ & $\begin{array}{l}0.000 \\
(0.000)\end{array}$ \\
\hline $\mathrm{E} 34 \times \mathrm{E} 34$ & $\begin{array}{l}-0.080 \\
(0.176)\end{array}$ & $\begin{array}{l}-0.104 \\
(0.103)\end{array}$ & $\begin{array}{l}0.057 \\
(0.065)\end{array}$ \\
\hline$E 567 \times E 567$ & $\begin{array}{l}-0.215 \\
(0.224)\end{array}$ & $\begin{array}{l}0.256^{*} \\
(0.131)\end{array}$ & $\begin{array}{l}-0.113 \\
(0.092)\end{array}$ \\
\hline $\begin{array}{l}\text { Hansen over-identification } \\
\text { test, } p \text { value }\end{array}$ & 0.607 & 0.680 & 0.258 \\
\hline $\begin{array}{l}\text { Arellano-Bond test for } \\
\operatorname{AR}(2), p \text { value }\end{array}$ & 0.117 & 0.125 & 0.228 \\
\hline Number of observations & 6714 & 6714 & 6714 \\
\hline Number of firms & 1844 & 1844 & 1844 \\
\hline \multicolumn{4}{|c|}{$\begin{array}{l}\text { Chi-squared statistic for equality } \\
\text { of regression coefficients, } \mathrm{H}_{0}\end{array}$} \\
\hline$E 34=E 567$ & 0.90 & 2.39 & $3.58^{*}$ \\
\hline \multirow[t]{2}{*}{ Interpretation ${ }^{\text {b }}$} & $\begin{array}{l}E 12=E 34 \\
E 34=E 567 \\
E 12=E 567\end{array}$ & $\begin{array}{l}\mathrm{E} 12=\mathrm{E} 34 \\
\mathrm{E} 12=\mathrm{E} 567 \\
\mathrm{E} 34=\mathrm{E} 567\end{array}$ & $\begin{array}{l}E 12<E 567 \\
E 34<E 567 \\
\text { but } \\
E 12=E 34\end{array}$ \\
\hline & $\begin{array}{l}\Rightarrow \text { Education has no } \\
\text { significant effect } \\
\text { productivity (but E567 } \\
>\text { E12 at } 14 \% \text { level) }\end{array}$ & $\begin{array}{l}\Rightarrow \text { Education has } \\
\text { no significant } \\
\text { effect on } \\
\text { wage costs (but } \\
\text { E567 > E34 at } 12 \% \\
\text { level) }\end{array}$ & $\begin{array}{l}\Rightarrow \text { E567 more } \\
\text { profitable } \\
\text { than E12 } \\
\text { and E34 }\end{array}$ \\
\hline
\end{tabular}

Notes: Standard errors, that are robust to heteroskedasticity and autocorrelation, are reported between parentheses. Regressions also control for: \% of workers with 10 years of tenure or more; \% workers younger than 30 and older than 49 years, respectively; \% women; \% part-time workers; \% blue-collar workers; $\%$ workers with fixed term employment contract; \% apprentices; \% temporary agency workers; In of firm size; level of collective wage bargaining; region where the firm is located (2 dummies); industries (8 dummies), and years dummies (11). AR (2) refers to second-order autocorrelation in first-differenced errors. GMM-SYS specifications include first and second lags of explanatory variables (except time dummies) as instruments

${ }^{* * *} p<0.01,{ }^{* * *} p<0.05,{ }^{*} p<0.1$

a Low-educated workers (E12) have at most a degree of lower secondary school. Middle-educated workers (E34)

have at most a degree from upper (general, technical or professional) secondary school. High-educated workers (E567) have a tertiary educational attainment (i.e. at least a Bachelor's or equivalent degree)

$\mathrm{b}^{\prime}<{ }^{\prime}\left({ }^{\prime}={ }^{\prime}\right)$ indicates if regression coefficients are (not) statistically different at the $10 \%$ level

c Value added-wage cost gap $=\ln$ (value added per hour) $-\ln$ (wage cost per hour)

${ }^{d}$ In of capital stock per worker 


\section{Appendix 4}

Table 8 Estimates for the entire sample, seven educational categories

\begin{tabular}{|c|c|c|c|c|}
\hline & \multicolumn{3}{|l|}{ GMM-SYS } & \multirow{2}{*}{$\begin{array}{l}\text { LP } \\
\text { Value added per } \\
\text { hour worked (In) }\end{array}$} \\
\hline & $\begin{array}{l}\text { Value added per } \\
\text { hour worked (In) }\end{array}$ & $\begin{array}{l}\text { Wage cost per } \\
\text { hour worked (In) }\end{array}$ & $\begin{array}{l}\text { Value added-wage } \\
\text { cost gap }\end{array}$ & \\
\hline & $(1)$ & (2) & (3) & \\
\hline Lagged dependent variable (In) & $\begin{array}{l}0.664^{* * *} \\
(0.056)\end{array}$ & $\begin{array}{l}0.471^{* * * *} \\
(0.137)\end{array}$ & $\begin{array}{l}0.466^{* * *} \\
(0.031)\end{array}$ & $\begin{array}{l}0.785^{* * * *} \\
(0.044)\end{array}$ \\
\hline \multicolumn{5}{|l|}{ Shares of workers } \\
\hline Primary education (E1) & Reference & Reference & Reference & Reference \\
\hline Lower secondary (E2) & $\begin{array}{l}0.018 \\
(0.028)\end{array}$ & $\begin{array}{l}-0.015 \\
(0.023)\end{array}$ & $\begin{array}{l}0.030 \\
(0.025)\end{array}$ & $\begin{array}{l}0.004 \\
(0.018)\end{array}$ \\
\hline $\begin{array}{l}\text { General upper secondary } \\
\text { education (E3) }\end{array}$ & $\begin{array}{l}0.068^{* *} \\
(0.030)\end{array}$ & $\begin{array}{l}0.001 \\
(0.022)\end{array}$ & $\begin{array}{l}0.064^{* *} \\
(0.026)\end{array}$ & $\begin{array}{l}0.037^{* *} \\
(0.017)\end{array}$ \\
\hline $\begin{array}{l}\text { Technical and professional } \\
\text { upper secondary education (E4) }\end{array}$ & $\begin{array}{l}0.068^{* *} \\
(0.030)\end{array}$ & $\begin{array}{l}0.023 \\
(0.023)\end{array}$ & $\begin{array}{l}0.041^{*} \\
(0.023)\end{array}$ & $\begin{array}{l}0.014 \\
(0.015)\end{array}$ \\
\hline $\begin{array}{l}\text { Bachelor's or equivalent level } \\
\text { (E5) }\end{array}$ & $\begin{array}{l}0.122^{* * * *} \\
(0.047)\end{array}$ & $\begin{array}{l}0.056 \\
(0.040)\end{array}$ & $\begin{array}{l}0.085^{* *} \\
(0.035)\end{array}$ & $\begin{array}{l}0.071^{* * * *} \\
(0.022)\end{array}$ \\
\hline Master's or equivalent level (E6) & $\begin{array}{l}0.199^{* * *} \\
(0.061)\end{array}$ & $\begin{array}{l}0.243^{* * * *} \\
(0.074)\end{array}$ & $\begin{array}{l}0.082^{*} \\
(0.042)\end{array}$ & $\begin{array}{l}0.205^{* * * *} \\
(0.055)\end{array}$ \\
\hline Post-Master's level or PhD (E7) & $\begin{array}{l}0.366^{* *} \\
(0.161)\end{array}$ & $\begin{array}{l}0.295^{*} \\
(0.163)\end{array}$ & $\begin{array}{l}0.235^{*} \\
(0.141)\end{array}$ & $\begin{array}{l}0.392^{* * * *} \\
(0.142)\end{array}$ \\
\hline $\begin{array}{l}\text { Hansen over-identification test, } p \\
\text { value }\end{array}$ & 0.487 & 0.154 & 0.686 & \\
\hline $\begin{array}{l}\text { Arellano-Bond test for } \operatorname{AR}(2), p \\
\text { value }\end{array}$ & 0.129 & 0.284 & 0.217 & \\
\hline Number of observations & 6714 & 6714 & 6714 & 6691 \\
\hline Number of firms & 1844 & 1844 & 1844 & 1844 \\
\hline \multicolumn{5}{|l|}{$\begin{array}{l}\text { Chi-squared statistic for equality } \\
\text { of regression coefficients, } \mathrm{H}_{0}\end{array}$} \\
\hline $\mathrm{E} 2=\mathrm{E} 3$ & $3.63^{*}$ & 1.36 & 1.78 & $4.72^{* *}$ \\
\hline$E 2=E 4$ & $4.40^{* *}$ & $5.13^{* *}$ & 0.28 & 0.55 \\
\hline$E 2=E 5$ & $5.21^{* *}$ & $2.81^{*}$ & $2.84^{*}$ & $11.67^{* * *}$ \\
\hline $\mathrm{E} 2=\mathrm{E} 6$ & $8.48^{* * *}$ & $10.61^{* * * *}$ & 1.41 & $14.22^{* * * *}$ \\
\hline $\mathrm{E} 2=\mathrm{E} 7$ & $4.65^{* *}$ & $3.47^{*}$ & 2.18 & $7.62^{* * *}$ \\
\hline $\mathrm{E} 3=\mathrm{E} 4$ & 0.00 & 2.14 & 1.34 & $3.35^{*}$ \\
\hline $\mathrm{E} 3=\mathrm{E} 5$ & 1.35 & 1.73 & 0.41 & 2.59 \\
\hline $\mathrm{E} 3=\mathrm{E} 6$ & $5.25^{* *}$ & $9.73^{*}$ & 0.20 & $12.78^{* * * *}$ \\
\hline $\mathrm{E} 3=\mathrm{E} 7$ & $3.51^{*}$ & $3.14^{*}$ & 1.55 & $6.20^{* *}$ \\
\hline $\mathrm{E} 4=\mathrm{E} 5$ & 1.33 & 0.57 & 1.94 & $6.64^{* * *}$ \\
\hline $\mathrm{E} 4=\mathrm{E} 6$ & $4.74^{* *}$ & $7.81^{* * *}$ & 1.02 & $14.60^{* * * *}$ \\
\hline $\mathrm{E} 4=\mathrm{E} 7$ & $3.48^{*}$ & 2.60 & 1.94 & $7.31^{* * *}$ \\
\hline $\mathrm{E} 5=\mathrm{E} 6$ & 1.14 & $8.75^{* * *}$ & 0.00 & $6.50^{* * *}$ \\
\hline $\mathrm{E} 5=\mathrm{E} 7$ & 2.37 & 2.64 & 1.10 & $5.78^{* *}$ \\
\hline $\mathrm{E} 6=\mathrm{E} 7$ & 1.16 & 0.15 & 1.22 & 1.39 \\
\hline \multirow[t]{2}{*}{ Interpretation ${ }^{\mathrm{a}}$ : } & $\begin{array}{l}E 1<E(3,4,5,6,7) \\
E 2<E(3,4,5,6,7) \\
E 3<E(4,5,6,7) \\
E 4<E(5,6,7) \\
E 5<E(6,7) \\
E 6<E 7\end{array}$ & $\begin{array}{l}E 1<E(6,7) \\
E 2<E(4,5,6,7) \\
E 3<E(6,7) \\
E 4<E 6 \\
E 5<E 6\end{array}$ & $\begin{array}{l}E 1<E(3,4,5,6,7) \\
E 2<E 5\end{array}$ & $\begin{array}{l}\mathrm{E} 1<\mathrm{E}(3,5,6,7) \\
\mathrm{E} 2<\mathrm{E}(3,5,6,7) \\
\mathrm{E} 3<\mathrm{E}(4,6,7) \\
\mathrm{E} 4<\mathrm{E}(5,6,7) \\
\mathrm{E} 5<\mathrm{E}(6,7)\end{array}$ \\
\hline & $\begin{array}{l}\Rightarrow \text { Education } \\
\text { increases } \\
\text { productivity }\end{array}$ & $\begin{array}{l}\Rightarrow \text { Education } \\
\text { increases } \\
\text { wage costs }\end{array}$ & $\begin{array}{l}\Rightarrow \text { Low-educated less } \\
\text { profitable than more } \\
\text { educated }\end{array}$ & $\begin{array}{l}\Rightarrow \text { Education } \\
\text { increases } \\
\text { productivity }\end{array}$ \\
\hline
\end{tabular}

Notes: Standard errors, that are robust to heteroskedasticity and autocorrelation, are reported between parentheses. Regressions also control for: $\%$ of workers with 10 years of tenure or more; $\%$ workers younger than 30 and older than 49 years, respectively; $\%$ women; $\%$ part-time workers; \% blue-collar workers; $\%$ workers with fixed term employment contract; $\%$ apprentices; $\%$ temporary agency workers; In of firm size; In of capital stock per worker; level of collective wage bargaining; region where the firm is located ( 2 dummies); industries (8 dummies), and years dummies (11). AR (2) refers to second-order autocorrelation in first-differenced errors. GMM-SYS specifications include first and second lags of explanatory variables (except time dummies) as instruments

s** $p<0.01,{ }^{* *} p<0.05,{ }^{*} p<0.1$

a ' $<$ ' indicates when regression coefficients are statistically different at the $10 \%$ level

${ }^{\mathrm{b}}$ Value added-wage cost gap $=\ln$ (value added per hour) $-\ln$ (wage cost per hour) 


\section{Appendix 5}

Table 9 Estimates for the entire sample, three educational categories, static GMM-SYS estimator

\begin{tabular}{|c|c|c|c|}
\hline & \multicolumn{3}{|l|}{ GMM-SYS } \\
\hline & $\begin{array}{l}\text { Value added per } \\
\text { hour worked (In) }\end{array}$ & $\begin{array}{l}\text { Wage cost per } \\
\text { hour worked (In) }\end{array}$ & $\begin{array}{l}\text { Value added-wage } \\
\text { cost gap }{ }^{c}\end{array}$ \\
\hline & $(1)$ & $(2)$ & (3) \\
\hline \multicolumn{4}{|l|}{ Shares of worker ${ }^{a}$} \\
\hline Low-educated (E12) & Reference & Reference & Reference \\
\hline Middle-educated (E34) & $\begin{array}{l}0.037 \\
(0.030)\end{array}$ & $\begin{array}{l}0.027 \\
(0.018)\end{array}$ & $\begin{array}{l}0.013 \\
(0.024)\end{array}$ \\
\hline High-educated (E567) & $\begin{array}{l}0.378^{* * *} \\
(0.069)\end{array}$ & $\begin{array}{l}0.286^{* * *} \\
(0.048)\end{array}$ & $\begin{array}{l}0.080^{*} \\
(0.047)\end{array}$ \\
\hline $\begin{array}{l}\text { Hansen over-identification test, } \\
p \text { value }\end{array}$ & 0.212 & 0.201 & 0.788 \\
\hline Arellano-Bond test for $A R(2), p$ value & 0.132 & 0.573 & 0.024 \\
\hline Number of observations & 6714 & 6714 & 6714 \\
\hline Number of firms & 1844 & 1844 & 1844 \\
\hline \multicolumn{4}{|l|}{$\begin{array}{l}\text { Chi-squared statistic for equality of } \\
\text { regression coefficients, } \mathrm{H}_{0}\end{array}$} \\
\hline $\mathrm{E} 34=\mathrm{E} 567$ & $27.09^{* *}$ & $29.36^{* * *}$ & $2.90^{*}$ \\
\hline \multirow[t]{2}{*}{ Interpretation $^{\text {b }}$} & $\begin{array}{l}E 12<E 567 \\
E 34<E 567 \\
\text { but } \\
E 12=E 34\end{array}$ & $\begin{array}{l}E 12<E 567 \\
E 34<E 567 \\
\text { but } \\
E 12=E 34\end{array}$ & $\begin{array}{l}E 12<E 567 \\
E 34<E 567 \\
\text { but } \\
E 12=E 34\end{array}$ \\
\hline & $\begin{array}{l}\Rightarrow \text { Education } \\
\text { increases } \\
\text { productivity }\end{array}$ & $\begin{array}{l}\Rightarrow \text { Education } \\
\text { increases } \\
\text { wage costs }\end{array}$ & $\begin{array}{l}\Rightarrow \text { Education } \\
\text { increases } \\
\text { profits }\end{array}$ \\
\hline
\end{tabular}

Notes: Standard errors, that are robust to heteroskedasticity and autocorrelation, are reported between parentheses. Regressions also control for: \% of workers with 10 years of tenure or more; \% workers younger than 30 and older than 49 years, respectively; \% women; \% part-time workers; \% blue-collar workers; \% workers with fixed term employment contract; \% apprentices; \% temporary agency workers; In of firm size; In of capital stock per worker; level of collective wage bargaining; region where the firm is located (2 dummies); industries (8 dummies), and years dummies (11). AR (2) refers to second-order autocorrelation in first-differenced errors. GMM-SYS specifications include first and second lags of explanatory variables (except time dummies) as instruments

${ }^{* * *} p<0.01,{ }^{* *} p<0.05,{ }^{*} p<0.1$

${ }^{\text {a }}$ Low-educated workers (E12) have at most a degree of lower secondary school. Middle-educated workers (E34) have at most a degree from upper (general, technical or professional) secondary school. High-educated workers (E567) have a tertiary educational attainment (i.e. at least a Bachelor's or equivalent degree)

$\mathrm{b}^{\prime}<^{\prime}\left({ }^{\prime}={ }^{\prime}\right)$ indicates if regression coefficients are (not) statistically different at the $10 \%$ level

c Value added-wage cost gap $=\ln$ (value added per hour) $-\ln$ (wage cost per hour) 


\section{Appendix 6}

Table 10 Firm-level shares of hours worked according to workers' educational level, age and gender (1999-2010)

\begin{tabular}{|c|c|c|c|c|c|c|c|}
\hline \multirow[t]{2}{*}{ Categories: } & $\begin{array}{l}\text { Lower } \\
\text { education } \\
\text { (E12) }\end{array}$ & $\begin{array}{l}\text { Middle } \\
\text { education } \\
\text { (E34) }\end{array}$ & $\begin{array}{l}\text { Higher } \\
\text { education } \\
\text { (E567) }\end{array}$ & $\begin{array}{l}\text { Primary } \\
\text { education } \\
\text { (E1) }\end{array}$ & $\begin{array}{l}\text { Lower \& } \\
\text { upper } \\
\text { secondary } \\
\text { (E234) }\end{array}$ & $\begin{array}{l}\text { Bachelor's } \\
\text { or } \\
\text { equivalent } \\
\text { level (E5) }\end{array}$ & $\begin{array}{l}\text { Master's or } \\
\text { equivalent level } \\
\text { \& Post-Master } \\
\text { and PhD (E67) }\end{array}$ \\
\hline & (1) & $(2)$ & (3) & (4) & (5) & (6) & (7) \\
\hline \multicolumn{8}{|l|}{ Age } \\
\hline Workers $<40$ years & 0.131 & 0.235 & 0.164 & 0.026 & 0.340 & 0.097 & 0.067 \\
\hline Workers $\geq 40$ years & 0.167 & 0.191 & 0.112 & 0.048 & 0.311 & 0.060 & 0.052 \\
\hline \multicolumn{8}{|l|}{ Gender } \\
\hline Women & 0.061 & 0.108 & 0.091 & 0.016 & 0.153 & 0.059 & 0.032 \\
\hline Men & 0.237 & 0.318 & 0.185 & 0.058 & 0.497 & 0.098 & 0.087 \\
\hline
\end{tabular}

Notes: Number of observations $=6714$. Number of firms $=1844$ 


\section{Appendix 7}

Table 11 Estimates according to workers' age (threshold $=40$ years ${ }^{\mathrm{a}}$ ), four educational categories

\begin{tabular}{|c|c|c|c|c|}
\hline & \multicolumn{3}{|l|}{ GMM-SYS } & \multirow{2}{*}{$\begin{array}{l}\text { LP } \\
\text { Value added per } \\
\text { hour worked (In) }\end{array}$} \\
\hline & $\begin{array}{l}\text { Value added per } \\
\text { hour worked (In) }\end{array}$ & $\begin{array}{l}\text { Wage cost per } \\
\text { hour worked (In) }\end{array}$ & $\begin{array}{l}\text { Value added-wage } \\
\text { cost gap }{ }^{c}\end{array}$ & \\
\hline & $(1)$ & $(2)$ & (3) & (4) \\
\hline $\begin{array}{l}\text { Lagged dependent variable } \\
\text { (In) }\end{array}$ & $\begin{array}{l}0.666^{* * *} \\
(0.055)\end{array}$ & $\begin{array}{l}0.477^{* * *} \\
(0.136)\end{array}$ & $\begin{array}{l}0.616^{* * *} \\
(0.045)\end{array}$ & $\begin{array}{l}0.787^{* * *} \\
(0.043)\end{array}$ \\
\hline \multicolumn{5}{|l|}{ Shares of workers } \\
\hline $\begin{array}{l}\text { Young \& primary } \\
\text { education (YE1) }\end{array}$ & $\begin{array}{l}-0.165^{* * *} \\
(0.062)\end{array}$ & $\begin{array}{l}-0.060 \\
(0.042)\end{array}$ & $\begin{array}{l}-0.096^{* *} \\
(0.044)\end{array}$ & $\begin{array}{l}-0.021 \\
(0.030)\end{array}$ \\
\hline $\begin{array}{l}\text { Older \& primary } \\
\text { education (OE1) }\end{array}$ & $\begin{array}{l}0.044 \\
(0.060)\end{array}$ & $\begin{array}{l}0.054 \\
(0.042)\end{array}$ & $\begin{array}{l}-0.025 \\
(0.052)\end{array}$ & $\begin{array}{l}-0.038 \\
(0.033)\end{array}$ \\
\hline $\begin{array}{l}\text { Young \& lower or upper } \\
\text { secondary education } \\
\text { (YE234) }\end{array}$ & Reference & Reference & Reference & Reference \\
\hline $\begin{array}{l}\text { Older \& lower or upper } \\
\text { secondary education } \\
\text { (OE234) }\end{array}$ & $\begin{array}{l}-0.027 \\
(0.047)\end{array}$ & $\begin{array}{l}0.006 \\
(0.032)\end{array}$ & $\begin{array}{l}-0.050 \\
(0.042)\end{array}$ & $\begin{array}{l}-0.029 \\
(0.027)\end{array}$ \\
\hline $\begin{array}{l}\text { Young \& Bachelor's or } \\
\text { equivalent degree (YE5) }\end{array}$ & $\begin{array}{l}0.130^{* *} \\
(0.063)\end{array}$ & $\begin{array}{l}0.057 \\
(0.047)\end{array}$ & $\begin{array}{l}0.074^{*} \\
(0.045)\end{array}$ & $\begin{array}{l}0.060^{*} \\
(0.032)\end{array}$ \\
\hline $\begin{array}{l}\text { Older \& Bachelor's or } \\
\text { equivalent degree (OE5) }\end{array}$ & $\begin{array}{l}-0.045 \\
(0.081)\end{array}$ & $\begin{array}{l}0.073 \\
(0.071)\end{array}$ & $\begin{array}{l}-0.050 \\
(0.061)\end{array}$ & $\begin{array}{l}-0.003 \\
(0.036)\end{array}$ \\
\hline $\begin{array}{l}\text { Young \& Master's or } \\
\text { equivalent degree or } \\
\text { beyond (YE67) }\end{array}$ & $\begin{array}{l}0.124 \\
(0.078)\end{array}$ & $\begin{array}{l}0.132^{*} \\
(0.075)\end{array}$ & $\begin{array}{l}0.072 \\
(0.049)\end{array}$ & $\begin{array}{l}0.201^{* * *} \\
(0.046)\end{array}$ \\
\hline $\begin{array}{l}\text { Older \& Master's or } \\
\text { equivalent degree or } \\
\text { beyond (OE67) }\end{array}$ & $\begin{array}{l}0.188^{* *} \\
(0.087)\end{array}$ & $\begin{array}{l}0.421^{* * *} \\
(0.123)\end{array}$ & $\begin{array}{l}-0.006 \\
(0.071)\end{array}$ & $\begin{array}{l}0.137^{* *} \\
(0.061)\end{array}$ \\
\hline $\begin{array}{l}\text { Hansen over-identification } \\
\text { test, } p \text { value }\end{array}$ & 0.474 & 0.402 & 0.606 & \\
\hline $\begin{array}{l}\text { Arellano-Bond test for } \\
\text { AR(2), } p \text { value }\end{array}$ & 0.124 & 0.287 & 0.217 & \\
\hline Number of observations & 6714 & 6714 & 6714 & 6691 \\
\hline Number of firms & 1844 & 1844 & 1844 & 1844 \\
\hline \multicolumn{5}{|c|}{$\begin{array}{l}\text { Chi-squared statistic for } \\
\text { equality of regression coefficients, } \mathrm{H}_{0}\end{array}$} \\
\hline$Y E 1=O E 1$ & $4.19^{* * *}$ & $2.65^{*}$ & 0.82 & 0.10 \\
\hline $\mathrm{YE} 1=\mathrm{OE} 234$ & $3.83^{*}$ & 2.26 & 0.64 & 0.04 \\
\hline$Y E 1=Y E 5$ & $13.53^{* * *}$ & $3.46^{*}$ & $8.12^{* * * *}$ & $2.78^{*}$ \\
\hline YE1 $=$ OE5 & 1.46 & 2.28 & 0.38 & 0.12 \\
\hline $\mathrm{YE1}=\mathrm{YE67}$ & $7.92^{* * * *}$ & $4.21^{*}$ & $7.09^{* * *}$ & $15.52^{* * *}$ \\
\hline YE1 = OE67 & $9.93^{* * * *}$ & $10.71^{* * *}$ & 1.05 & $4.85^{* *}$ \\
\hline $\mathrm{OE} 1=\mathrm{OE} 231$ & 1.92 & 1.29 & 0.38 & 0.16 \\
\hline $\mathrm{OE} 1=\mathrm{YE} 5$ & 1.04 & 0.00 & 2.19 & $5.11^{* * *}$ \\
\hline $\mathrm{OE} 1=\mathrm{OE} 5$ & 1.12 & 0.08 & 0.17 & 1.07 \\
\hline $\mathrm{OE} 1=\mathrm{YE} 67$ & 0.84 & 1.25 & 1.98 & $19.38^{* * *}$ \\
\hline $\mathrm{OE} 1=\mathrm{OE} 67$ & 2.27 & $10.51^{* * *}$ & 0.06 & $7.98^{* * *}$ \\
\hline OE234 = YE5 & $4.83^{* *}$ & 1.12 & $5.02^{* *}$ & $4.71^{* *}$ \\
\hline OE234 = OE5 & 0.06 & 0.87 & 0.00 & 0.62 \\
\hline OE234 = YE67 & $3.12^{*}$ & $2.77^{*}$ & $4.05^{* *}$ & $20.36^{* * *}$ \\
\hline OE234 = OE67 & $5.37^{* *}$ & $9.93^{* * *}$ & 0.34 & $7.62^{* * *}$ \\
\hline YE5 $=$ OE5 & $2.83^{*}$ & 0.04 & 2.47 & 1.60 \\
\hline YE5 = YE67 & 0.00 & 1.01 & 0.00 & $8.46^{* * *}$ \\
\hline $\mathrm{YE5}=\mathrm{OE} 67$ & 0.28 & $9.51^{* * *}$ & 0.78 & 2.08 \\
\hline $\mathrm{OE5}=\mathrm{YE} 67$ & $2.90^{*}$ & 0.60 & $2.93^{*}$ & $13.28^{* * *}$ \\
\hline $\mathrm{OE} 5=\mathrm{OE} 67$ & $5.09^{* * *}$ & $11.73^{* * *}$ & 0.29 & $4.63^{* *}$ \\
\hline YE67 $=0 \mathrm{E} 67$ & 0.30 & $6.82^{* * *}$ & 0.71 & 0.91 \\
\hline
\end{tabular}




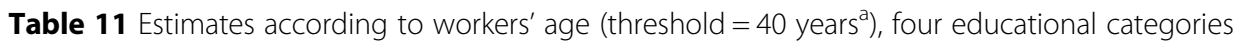
(Continued)

\begin{tabular}{|c|c|c|c|c|c|}
\hline & & \multicolumn{3}{|l|}{ GMM-SYS } & \multirow{2}{*}{$\begin{array}{l}\text { LP } \\
\text { Value added per } \\
\text { hour worked (In) }\end{array}$} \\
\hline & & $\begin{array}{l}\text { Value added per } \\
\text { hour worked (In) }\end{array}$ & $\begin{array}{l}\text { Wage cost per } \\
\text { hour worked (In) }\end{array}$ & $\begin{array}{l}\text { Value added-wage } \\
\text { cost gap }{ }^{c}\end{array}$ & \\
\hline & & (1) & (2) & (3) & (4) \\
\hline \multicolumn{6}{|c|}{ Interpretation $^{\mathrm{b}}$} \\
\hline & $\begin{array}{l}\text { a) Among young } \\
\text { workers }\end{array}$ & $\begin{array}{l}Y E 1<Y E 234 \\
Y E 234<Y E 5 \\
Y E 1<Y E 5 \\
Y E 1<Y E 67 \\
\text { but } \\
\text { YE234 = YE67 } \\
\text { YE5 = YE67 }\end{array}$ & $\begin{array}{l}\text { YE1 < YE5 } \\
\text { YE1 < YE67 } \\
\text { YE234 < YE67 } \\
\text { but } \\
\text { YE1 = YE234 } \\
\text { YE234 = YE5 } \\
\text { YE5 }=\text { YE67 }\end{array}$ & $\begin{array}{l}Y E 1<Y E 234 \\
Y E 1<Y E 5 \\
Y E 1<Y E 67 \\
Y E 234<Y E 5 \\
\text { but } \\
\text { YE234 = YE67 } \\
\text { YE5 = YE67 }\end{array}$ & $\begin{array}{l}Y E 234<Y E 5 \\
Y E 5<Y E 67 \\
Y E 1<Y E 5 \\
Y E 1<Y E 67 \\
Y E 234<Y E 67 \\
\text { but } \\
Y E 1=Y E 234\end{array}$ \\
\hline & & $\begin{array}{l}\Rightarrow \text { Education increases } \\
\text { productivity significantly }\end{array}$ & $\begin{array}{l}\Rightarrow \text { High-educated } \\
\text { significantly more costly }\end{array}$ & $\begin{array}{l}\Rightarrow \text { Education increases } \\
\text { profits significantly }\end{array}$ & $\begin{array}{l}\Rightarrow \text { Education increases } \\
\text { productivity significantly }\end{array}$ \\
\hline \multirow[t]{2}{*}{ a) } & $\begin{array}{l}\text { b) Among older } \\
\text { workers }\end{array}$ & $\begin{array}{l}\text { OE5 }<\text { OE67 } \\
\text { OE234 < OE67 } \\
\text { but } \\
\text { OE1 = OE67 } \\
\text { OE1 = OE234 } \\
\text { OE234 = OE5 }\end{array}$ & $\begin{array}{l}\text { OE5 }<\text { OE67 } \\
\text { OE1 }<\text { OE67 } \\
\text { OE234 }<\text { OE67 } \\
\text { but } \\
\text { OE1 = OE234 } \\
\text { OE234 = OE5 } \\
\text { OE1 = OE5 }\end{array}$ & $\begin{array}{l}\mathrm{OE} 1=\mathrm{OE} 234 \\
\mathrm{OE} 1=\mathrm{OE} 5 \\
\mathrm{OE} 1=\mathrm{OE} 67 \\
\mathrm{OE} 234=\mathrm{OE} 5 \\
\mathrm{OE} 234=\mathrm{OE} 67 \\
\mathrm{OE} 5=\mathrm{OE} 67\end{array}$ & $\begin{array}{l}\text { OE5 < OE67 } \\
\text { OE1 }<\text { OE67 } \\
\text { OE234 }<\text { OE67 } \\
\text { but } \\
\text { OE1 = OE234 } \\
\text { OE234 = OE5 } \\
\text { OE1 = OE5 }\end{array}$ \\
\hline & & $\begin{array}{l}\Rightarrow \text { High-educated workers } \\
\text { significantly more } \\
\text { productive }\end{array}$ & $\begin{array}{l}\Rightarrow \text { High-educated } \\
\text { workers significantly } \\
\text { more costly }\end{array}$ & $\begin{array}{l}\Rightarrow \text { Education has no } \\
\text { significant effect on } \\
\text { profitability }\end{array}$ & $\begin{array}{l}\Rightarrow \text { High-educated workers } \\
\text { significantly more } \\
\text { productive }\end{array}$ \\
\hline
\end{tabular}

Notes: Standard errors, that are robust to heteroskedasticity and autocorrelation, are reported between parentheses. Regressions also control for: \% of workers with 10 years of tenure or more; \% workers younger than 30 and older than 49 years, respectively; $\%$ women; \% part-time workers; $\%$ blue-collar workers; $\%$ workers with fixed term employment contract; $\%$ apprentices; $\%$ temporary agency workers; In of firm size; In of capital stock per worker; level of collective wage bargaining; region where the firm is located (2 dummies); industries (8 dummies), and years dummies (11). AR (2) refers to second-order autocorrelation in first-differenced errors. GMM-SYS specifications include first and second lags of explanatory variables (except time dummies) as instruments $p<0.01,{ }^{* * *} p<0.05,{ }^{*} p<0.1$

a Young (older) workers are defined as being less than (at least) 40 years old

$b^{\prime}$ ' $<$ ' (' $=$ ') indicates if regression coefficients are (not) statistically different at the $10 \%$ level

c Value added-wage cost gap $=\ln ($ value added per hour) $-\ln ($ wage cost per hour) 


\section{Appendix 8}

Table 12 Estimates according to workers' gender, four educational categories

\begin{tabular}{|c|c|c|c|c|}
\hline & \multicolumn{3}{|l|}{ GMM-SYS } & \multirow{2}{*}{$\begin{array}{l}\text { LP } \\
\text { Value added per } \\
\text { hour worked (In) }\end{array}$} \\
\hline & $\begin{array}{l}\text { Value added per } \\
\text { hour worked (In) }\end{array}$ & $\begin{array}{l}\text { Wage cost per } \\
\text { hour worked (In) }\end{array}$ & $\begin{array}{l}\text { Value added-wage } \\
\text { cost gap }{ }^{b}\end{array}$ & \\
\hline & $(1)$ & (2) & (3) & \\
\hline $\begin{array}{l}\text { Lagged dependent } \\
\text { variable }(\mathrm{In})\end{array}$ & $\begin{array}{l}0.664^{* * *} \\
(0.056)\end{array}$ & $\begin{array}{l}0.462^{* * *} \\
(0.135)\end{array}$ & $\begin{array}{l}0.627^{* * *} \\
(0.043)\end{array}$ & $\begin{array}{l}0.786^{* * *} \\
(0.042)\end{array}$ \\
\hline \multicolumn{5}{|l|}{ Shares of workers } \\
\hline $\begin{array}{l}\text { Female \& primary } \\
\text { education (FE1) }\end{array}$ & $\begin{array}{l}-0.131^{*} \\
(0.070)\end{array}$ & $\begin{array}{l}-0.093 \\
(0.058)\end{array}$ & $\begin{array}{l}-0.031 \\
(0.048)\end{array}$ & $\begin{array}{l}-0.081^{* * *} \\
(0.030)\end{array}$ \\
\hline $\begin{array}{l}\text { Male \& primary } \\
\text { education (ME1) }\end{array}$ & $\begin{array}{l}0.028 \\
(0.054)\end{array}$ & $\begin{array}{l}0.076^{*} \\
(0.043)\end{array}$ & $\begin{array}{l}-0.129^{*} \\
(0.072)\end{array}$ & $\begin{array}{l}0.005 \\
(0.020)\end{array}$ \\
\hline $\begin{array}{l}\text { Female \& lower or } \\
\text { upper secondary } \\
\text { education (FE234) }\end{array}$ & Reference & Reference & Reference & Reference \\
\hline $\begin{array}{l}\text { Male \& lower or } \\
\text { upper secondary } \\
\text { education (ME234) }\end{array}$ & $\begin{array}{l}0.037 \\
(0.053)\end{array}$ & $\begin{array}{l}0.062 \\
(0.039)\end{array}$ & $\begin{array}{l}-0.104 \\
(0.065)\end{array}$ & $\begin{array}{l}0.003 \\
(0.016)\end{array}$ \\
\hline $\begin{array}{l}\text { Female \& } \\
\text { Bachelor's or } \\
\text { equivalent degree } \\
\text { (FE5) }\end{array}$ & $\begin{array}{l}0.141^{*} \\
(0.073)\end{array}$ & $\begin{array}{l}0.069 \\
(0.071)\end{array}$ & $\begin{array}{l}0.125^{*} \\
(0.064)\end{array}$ & $\begin{array}{l}0.069^{*} \\
(0.036)\end{array}$ \\
\hline $\begin{array}{l}\text { Male \& Bachelor's } \\
\text { or equivalent } \\
\text { degree (ME5) }\end{array}$ & $\begin{array}{l}0.048 \\
(0.069)\end{array}$ & $\begin{array}{l}0.107^{*} \\
(0.055)\end{array}$ & $\begin{array}{l}-0.138^{*} \\
(0.079)\end{array}$ & $\begin{array}{l}0.037 \\
(0.032)\end{array}$ \\
\hline $\begin{array}{l}\text { Female \& Master's } \\
\text { or equivalent } \\
\text { degree or beyond } \\
\text { (FE67) }\end{array}$ & $\begin{array}{l}0.156 \\
(0.121)\end{array}$ & $\begin{array}{l}0.182 \\
(0.121)\end{array}$ & $\begin{array}{l}0.087 \\
(0.075)\end{array}$ & $\begin{array}{l}0.212^{* *} \\
(0.090)\end{array}$ \\
\hline $\begin{array}{l}\text { Male \& Master's or } \\
\text { equivalent degree } \\
\text { or beyond (ME67) }\end{array}$ & $\begin{array}{l}0.172^{* *} \\
(0.074)\end{array}$ & $\begin{array}{l}0.339^{* * *} \\
(0.092)\end{array}$ & $\begin{array}{l}-0.093 \\
(0.081)\end{array}$ & $\begin{array}{l}0.184^{* * *} \\
(0.035)\end{array}$ \\
\hline $\begin{array}{l}\text { Hansen } \\
\text { over-identification } \\
\text { test, } p \text { value }\end{array}$ & 0.373 & 0.297 & 0.209 & \\
\hline $\begin{array}{l}\text { Arellano-Bond test } \\
\text { for } A R(2), p \text { value }\end{array}$ & 0.125 & 0.289 & 0.561 & \\
\hline $\begin{array}{l}\text { Number of } \\
\text { observations }\end{array}$ & 6714 & 6714 & 6714 & 6691 \\
\hline Number of firms & 1844 & 1844 & 1844 & 1844 \\
\hline \multicolumn{5}{|c|}{$\begin{array}{l}\text { Chi-squared statistic } \\
\text { for equality of } \\
\text { regression coefficients, } \mathrm{H}_{0}\end{array}$} \\
\hline $\mathrm{FE} 1=\mathrm{ME} 1$ & $4.01^{* *}$ & $6.13^{* *}$ & 1.12 & $7.17^{* * *}$ \\
\hline $\mathrm{FE} 1=\mathrm{ME} 234$ & $5.95^{* *}$ & $7.07^{* * *}$ & 0.80 & $9.45^{* * *}$ \\
\hline $\mathrm{FE} 1=\mathrm{FE} 5$ & $8.80^{* * *}$ & $3.42^{*}$ & $5.23^{* *}$ & $13.61^{* * *}$ \\
\hline $\mathrm{FE} 1=\mathrm{ME} 5$ & $4.63^{* *}$ & $7.89^{* * *}$ & 1.25 & $7.65^{* * *}$ \\
\hline $\mathrm{FE} 1=\mathrm{FE} 67$ & $4.09^{* *}$ & $3.98^{* *}$ & 1.94 & $9.56^{* * *}$ \\
\hline $\mathrm{FE} 1=\mathrm{ME} 67$ & $11.08^{* * *}$ & $16.81^{* * *}$ & 0.37 & $35.21^{* * *}$ \\
\hline ME1 = ME234 & 0.09 & 0.33 & 0.83 & 0.01 \\
\hline $\mathrm{ME} 1=\mathrm{FE} 5$ & 1.92 & 0.01 & $6.13^{*}$ & $3.03^{*}$ \\
\hline ME1 = ME5 & 0.10 & 0.35 & 0.03 & 0.91 \\
\hline $\mathrm{ME} 1=\mathrm{FE} 67$ & 0.97 & 0.84 & $3.77^{*}$ & $5.79^{* *}$ \\
\hline
\end{tabular}


Table 12 Estimates according to workers' gender, four educational categories (Continued)

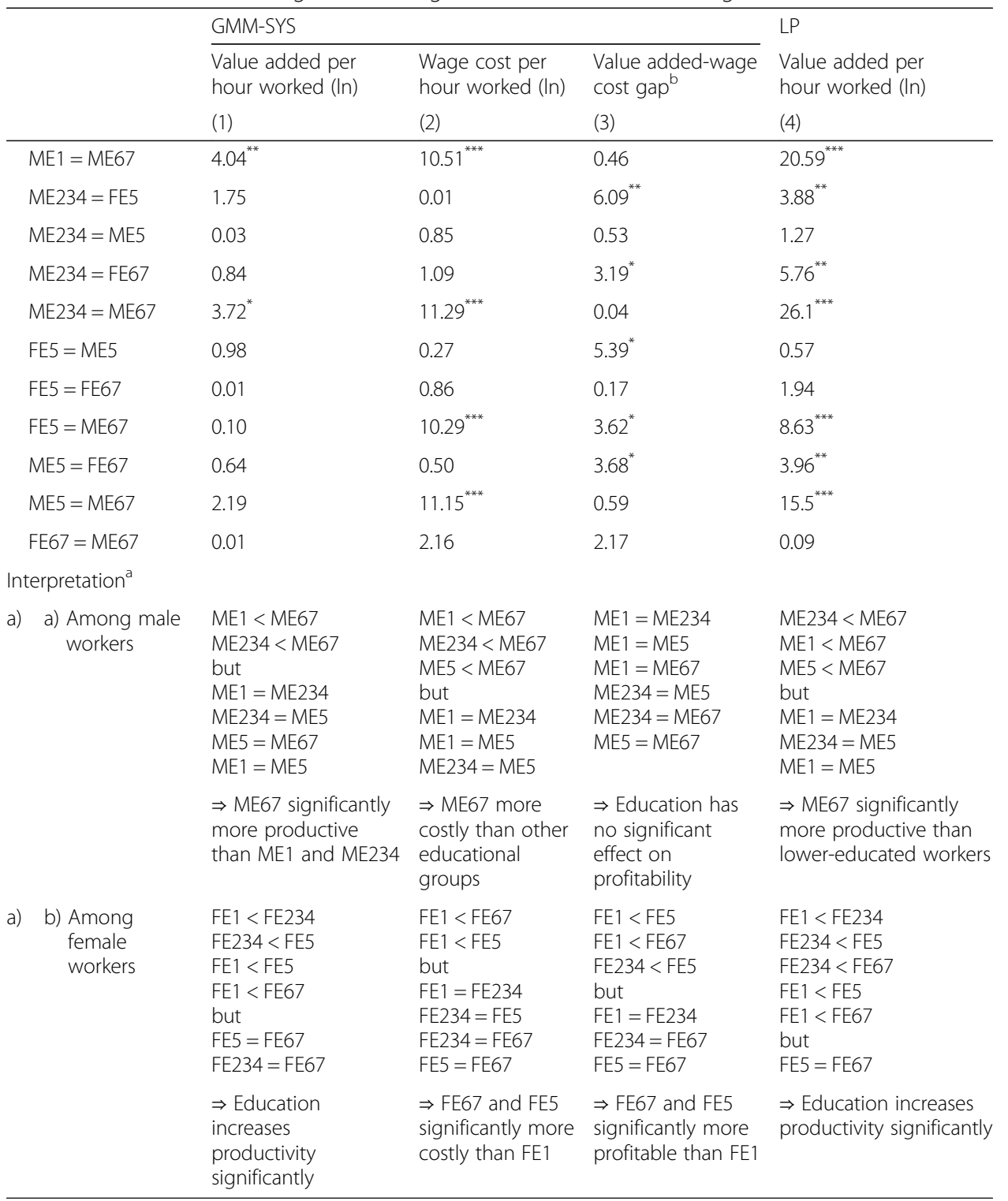

Notes: Standard errors, that are robust to heteroskedasticity and autocorrelation, are reported between parentheses. Regressions also control for: \% of workers with 10 years of tenure or more; \% workers younger than 30 and older than 49 years, respectively; \% women; \% part-time workers; \% blue-collar workers; \% workers with fixed term employment contract; \% apprentices; \% temporary agency workers; In of firm size; In of capital stock per worker; level of collective wage bargaining; region where the firm is located (2 dummies); industries (8 dummies), and years dummies (11). AR (2) refers to second-order autocorrelation in first-differenced errors. GMM-SYS specifications include first and second lags of explanatory variables (except time dummies) as instruments

${ }^{* * *} p<0.01,{ }^{* *} p<0.05,{ }^{*} p<0.1$

$a^{\prime}{ }^{\prime}<{ }^{\prime}\left({ }^{\prime}={ }^{\prime}\right)$ indicates if regression coefficients are (not) statistically different at the $10 \%$ level

${ }^{\mathrm{b}}$ Value added-wage cost gap $=\ln$ (value added per hour) $-\ln$ (wage cost per hour) 


\section{Appendix 9}

Table 13 Average shares and standard variations of educational variables in different SES-SBS sub-samples (1999-2010)

\begin{tabular}{|c|c|c|c|}
\hline Sample & Full sample & Non-missing information & GMM-SYS sample \\
\hline \multirow[t]{2}{*}{ Low-educated (E12) } & 32.7 & 30.3 & 29.8 \\
\hline & $(33.1)$ & $(30.3)$ & $(29.5)$ \\
\hline \multirow[t]{2}{*}{ Middle-educated (E34) } & 42.2 & 42.6 & 42.6 \\
\hline & $(30.3)$ & $(27.9)$ & $(26.8)$ \\
\hline \multirow[t]{2}{*}{ High-educated (E567) } & 24.1 & 27.1 & 27.6 \\
\hline & $(27.6)$ & $(26.0)$ & $(25.1)$ \\
\hline Number of firm-year observations & 33,169 & 10,874 & 6713 \\
\hline Number of firms & 12,306 & 3225 & 1844 \\
\hline $\begin{array}{l}\text { Average number of observations } \\
\text { per firm }\end{array}$ & 2.7 & 3.4 & 3.6 \\
\hline
\end{tabular}




\section{Appendix 10}

\subsection{Stratification criteria of the SES}

The stratification criteria used in the SES refer respectively to the region (NUTS groups), the principal economic activity (NACE groups) and the size of the firm. The sample size in each stratum depends on the size of the firm. Sampling percentages of firms are respectively equal to 10,50 and $100 \%$ when the number of workers is lower than 50 , between 50 and 99, and above 100. Within a firm, sampling percentages of employees also depend on size. Sampling percentages of employees reach respectively 100, 50, 25, 14.3 and $10 \%$ when the number of workers is lower than 20, between 20 and 50, between 50 and 99, between 100 and 199, and between 200 and 299. Firms employing 300 workers or more have to report information for an absolute number of employees. This number ranges between 30 (for firms with between 300 and 349 workers) and 200 (for firms with 12,000 workers or more). To guarantee that firms report information on a representative sample of their workers, they are asked to follow a specific procedure. First, they have to rank their employees in alphabetical order. Next, Statistics Belgium gives them a random letter (e.g. the letter O) from which they have to start when reporting information on their employees (following the alphabetical order of workers' names in their list). If they reach the letter $\mathrm{Z}$ and still have to provide information on some of their employees, they have to continue from the letter A in their list. Moreover, firms that employ different categories of workers, namely managers, blue- and/or white-collar workers, have to set up a separate alphabetical list for each of these categories and to report information on a number of workers in these different groups that is proportional to their share in the firm's total employment. For example, a firm with 300 employees (namely, 60 managers, 180 white-collar workers and 60 blue-collar workers) will have to report information on 30 workers (namely, 6 managers, 18 white-collar workers and 6 blue-collar workers). For more details see Demunter (2000).

We are grateful to the National Bank of Belgium (NBB) for financial support and to Statistics Belgium (DGSIE) for giving access to the data. We also would like to thank Philippe Delhez, Francesco Devicienti, Catherine Fuss, Maarten Goos, Wolter Hassink, Sile O'Dorchai, Raul Ramos, Bruno Van der Linden, Vincent Vandenberghe, Dieter Verhaest, Raf Wouters and participants at various conferences and seminars (notably at the University of Barcelona and Utrecht and at the SOLE, EALE, LEER, NBB, IWEPS, Meet2Know, Skill Mismatch and USE conferences) for very helpful comments on an earlier version of this paper. We would also like to thank the anonymous referees and the editor for the helpful remarks. The views expressed here are our own and do not necessarily reflect those of the NBB. None of the authors have any competing interests in the manuscript.

Responsible editor: Pierre Cahuc.

\section{Competing interests}

The IZA Journal of Labor Economics is committed to the IZA Guiding Principles of Research Integrity. The authors declare that they have observed these principles.
}

\section{Publisher's Note}

Springer Nature remains neutral with regard to jurisdictional claims in published maps and institutional affiliations.

\section{Author details}

${ }^{1}$ Université libre de Bruxelles, SBS-EM, CEB and DULBEA, Avenue F. Roosevelt, 50, B-1050 Brussels, Belgium. ${ }^{2}$ National Bank of Belgium, Boulevard du Berlaimont, 14, B-1000 Brussels, Belgium. ${ }^{3}$ IZA, Bonn, Germany. ${ }^{4}$ IRES, Louvain-la Neuve, Belgium. ${ }^{5}$ humanOrg, Mons, Belgium.

Received: 3 February 2017 Accepted: 18 December 2017

Published online: 23 January 2018

References

Akerlof G, Yellen J (1988) Fairness and unemployment. Am Econ Rev 78:44-49

Altonji J, Pierret C (2001) Employer learning and statistical discrimination. Q J Econ 116:313-350 
Arellano M, Bond O (1991) Some tests of specification for panel data: Monte Carlo evidence and an application to employment equations. Rev Econ Stud 58:277-297

Arellano M, Bover O (1995) Another look at the instrumental variable estimation of error-component models. J Econ 68:28-51 Bartolucci C (2013) Gender wage gaps reconsidered a structural approach using matched employer-employee data. J Hum Resour 48(4):998-1034

Bebchuk L, Fried J (2003) Executive compensation as an agency problem. J Econ Perspect 17:71-92

Becker G (1964) Human capital. NBER, New York

Belgian federal government 2015. National plan programme 2015, Brussels

Berg I (1981) Sociological perspectives on labor markets. London: Academic Press

Blundell R, Bond S (1998) Initial conditions and moment restrictions in dynamic panel data models. J Econ 87:115-143

Bond S (2002) Dynamic panel data models: a guide to micro data methods and practice. Port Econ J 1:141-162

Bond, S., and Söderbom, M. 2005. 'Adjustment costs and the identification of Cobb Douglas production functions.' IFS Working Paper, No. 05/04, London

Bou J, Satorra A (2007) The persistence of abnormal returns at industry and firm levels: evidence from Spain. Strateg Manag J 28:707-722

Cahuc P, Carcillo S (2012) Les conséquences des allègements généraux de cotisations patronales sur les bas salaires. Revue Française d'économie 27:19-61

Cahuc P, Zylberberg A (2014) Labor economics. MIT Press, Cambridge

Card D, Cardoso A, Kline P (2016) Bargaining and the gender wage gap: a direct assessment. Q J Econ 131:633-686

Card D, Kluve J, Weber A (2010) Active labour market policy evaluations: a meta-analysis. Econ J 120:F452-F477

Cardoso A (2010) Do firms compress the wage distribution. In: Marsden D (ed) Wage structures, employment adjustments and globalisation: evidence from linked and firm-level panel data, Palgrave Macmillan, pp 202-218

Cardoso A, Guimaraes P, Varejao J (2011) Are older workers worthy of their pay? An empirical investigation of ageproductivity and age-wage nexuses. De Economist 159:95-111

Cataldi A, Kampelmann S, Rycx F (2011) Productivity-wage gaps among age groups: does the ICT environment matter? De Economist 159(2):193-221

Cockx, B., and Dejemeppe, M. 2002. 'Do the higher educated unemployed crowd out the lower educated ones in competition for jobs?', IZA Discussion Paper, No. 541, Bonn

Demunter C (2000) Structure and dispersion of earnings survey. Working Paper, Statistics Belgium, Brussels

Devicienti, F., Grinza, E. and Vannoni, D. 2017. The impact of part-time work on firm total factor productivity: evidence from Italy.' Industrial and Corporate Change, forthcoming

Doeringer P, Piore M. (1985) Internal labor markets and manpower analysis. ME Sharpe, Armonk.

Dolado J, Felgueroso F, Jimeno J (2000) Youth labour markets in Spain: education, training crowding out. Eur Econ Rev 44:943-956

Eurostat (2016a) Labour force survey. Eurostat, Luxemburg

Eurostat (2016b) Labour market policy - expenditure and participants - data 2013. Eurostat, Luxembourg

Fuss, C., and Wintr, L. 2009. 'Rigid labour compensation and flexible employment? Firm-level evidence with regard to productivity for Belgium', ECB Working Paper, No. 1021, Frankfurt

Galindo-Rueda, F., and Haskel, J. 2005. 'Skills, workforce characteristics and firm-level productivity: evidence from the matched ABI/employer skills survey', IZA Discussion Paper, No. 1542, Bonn

Garnero A, Kampelmann S, Rycx F (2014) Part-time work, wages and productivity: evidence from Belgian matched panel data. Ind Labor Relat Rev 67:926-954

Gautier P, van den Berg G, van Ours J, Ridder G (2002) Worker turnover at the firm level and crowding out of lower educated workers. Eur Econ Rev 46:523-538

Giuliano R, Kampelmann S, Mahy B, Rycx F (2017) Short notice, big difference? The effect of temporary employment on firm competitiveness across sectors. Br J Ind Relat 55:421-449

Göbel C, Zwick T (2012) Age and productivity: sector differences. De Economist 160:35-57

Goos M, Manning A, Salomons A (2014) Explaining job polarization: routine-biased technological change and offshoring. Am Econ Rev 104:2509-2526

Haegeland T, Klette T (1999) Do higher wages reflect higher productivity? Education, gender and experience premiums in a matched plant-worker data set. In: Haltiwanger J, Lane J, Spletzer J, Theeuwes J, Troske K (eds) The creation and analysis of employer-employee matched data. Elsevier, North-Holland, pp 231-259

Haltiwanger J, Lane J, Spetze J (1999) Productivity differences across employers: the roles of employer size, age and human capital. Am Econ Rev 89:94-98

Hamermesh D (1975) Interdependence in the labour market. Economica 42:420-429

Hansen L (1982) Large sample properties of generalized method of moment estimators. Econometrica 50:1029-1054

Heckman J, LaLonde R, Smith J (1999) The economics and econometrics of active labor market programs. In: Ashenfelter O, Card D (eds) Handbook of labor economics. Elsevier, Amsterdam, pp 1865-2097

Hellerstein, J., and Neumark, D. 2004. 'Production function and wage equation estimation with heterogeneous labor: evidence from a new matched employer-employee data set', NBER Working Paper, No. 10365, Cambridge (Ma.)

Hellerstein J, Neumark D, Troske K (1999a) Sex, wages, productivity: an empirical analysis of Israel firm-level data. Int Econ Rev 40:95-123 Hellerstein J, Neumark D, Troske K (1999b) Wages, productivity and worker characteristics: evidence from plantlevel production functions and wage equations. J Labor Econ 17:409-446

Hempell T. (2005) What's spurious? What's real? Measuring the productivity impacts of ICT at the firm level. Empir Econ 30:427-464.

IImakunnas P, Maliranta M (2005) Technology, labour characteristics and wage-productivity gaps. Oxf Bull Econ Stat 67:623-645

Kalleberg A, Sørensen A (1979) The sociology of labor markets. Annu Rev Sociol 5:351-379

Kampelmann S, Rycx F (2012) Are occupations paid what they are worth? An econometric study of occupational wage inequality and productivity. De Economist 160:257-287

Kampelmann S, Rycx F (2013) Does institutional diversity account for pay rules in Germany and Belgium? Soc Econ Rev 11:131-157 2013

Kluve J (2010) The effectiveness of European active labor market programs. Labour Econ 17:904-918

Koyck L (1954) Distributed lags and investment analysis. Amsterdam: North Holland 
Krueger A, Lindahl M (2001) Education and growth: why and for whom? J Econ Lit 39:1101-1136

Lazear E, Rosen S (1981) Rank-order tournaments as optimum labor contracts. J Polit Econ 89:841-864

Lazear E, Shaw K (2007) Personnel economics: the economist's view of human resources. J Econ Perspect 21:91-114

Levinsohn J, Petrin A (2003) Estimating production functions using inputs to control for unobservables. Rev Econ Stud 70:317-341

Mahlberg B, Freund I, Cuaresma J, Prskawets A (2013) Ageing productivity and wages in Austria. Labour Econ 22:5-15

McGuinness S (2006) Overeducation in the labour market. J Econ Surv 20:238-418

Montt G (2017) Field-of-study mismatch and overqualification: labour market correlates and their wage penalty. IZA J Labor Econ 6:2

Moretti E (2004) Workers' education, spillovers and productivity: evidence from plant-level production functions. Am Econ Rev 94:656-690

Nielen S, Schiersch A (2014) Temporary agency work and firm competitiveness: evidence from German manufacturing firms. Ind Relat 53:365-393

OECD (2009) Measuring capital. OECD, Paris

OECD (2015) OECD employment outlook 2015. OECD, Paris

Osterman P, Auer P, Gautié J, Marsden D (2009) Discussion: a new labour economics? Soc Econ Rev 7:695-726

Roodman D (2009) How to do xtabond2: an introduction to difference and system GMM in Stata. Stata J 9:86-136

Rycx, F., Saks, Y., and Tojerow, I. 2015. 'Does education raise productivity and wages equally? The moderating roles of age, gender and industry', IZA Discussion Paper, No. 9043, Bonn

Sianesi B, Van Reenen J (2003) The returns to education: macroeconomics. J Econ Surv 17:157-200

Skott $P$ (2005) Fairness as a source of hysteresis in employment and relative wages. J Econ Behav Organ 57:305-331

Syverson C (2011) What determines productivity? J Econ Lit 49:326-365

Van Beveren I (2012) Total factor productivity estimation: a practical review. J Econ Surv 26:98-128

Van Biesebroeck J (2011) Wages equal productivity. Fact or fiction? Evidence from sub-Saharan Africa. World Econ 39 : 1333-1346

van Ours J, Stoeldraijer L (2011) Age, wage and productivity in Dutch manufacturing. De Economist 159:113-137

Vandenberghe V, Waltenberg F, Rigo M (2013) Ageing and employability. Evidence from Belgian firm-level data. J Prod Anal 40:111-136

Weeden K (2002) Why do some occupations pay more than others? Social closure and earnings inequality in the United States. Am J Sociol 108:55-101

Wooldridge J (2010) Econometric analysis of cross section and panel data. MIT Press, Cambridge (Ma.)

Submit your manuscript to a SpringerOpen ${ }^{\odot}$ journal and benefit from:

- Convenient online submission

- Rigorous peer review

Open access: articles freely available online

High visibility within the field

Retaining the copyright to your article

Submit your next manuscript at $>$ springeropen.com 